\title{
ANALISA PERAN MANAJEMEN STRES SEBAGAI MEDIASI PENGARUH STRES DAN KEPUASAN KERJA TERHADAP KINERJA
}

\author{
Renny Resiana ${ }^{1}$, Maria Widyarini ${ }^{2}$ \\ ${ }^{1}$ Perusahaan Keuangan Swasta, Bandung \\ ${ }^{2}$ Dosen, Bandung \\ ${ }^{1}$ renny.resiana@gmail.com \\ ${ }^{2}$ widya@unpar.ac.id
}

\begin{abstract}
ABSTRAK
Tujuan dari penelitian ini adalah untuk menganalisa pengaruh stres dan kepuasan kerja karyawan terhadap kinerja yang dimediasi oleh manajemen stres di PT Bank X Region Jawa Barat.Penelitian ini menggunakan metode studi kasus dalam bentuk metode kuantitatif berupa penyebaran kuesioner dan triangulasi dengan carasemi-structured interview. Teknik analisis data menggunakan software SPSS dengan tingkat kepercayaan 90\% dan pengujian model menggunakan Structural Equation Modelling (SEM) jenis PLS (Partial Least Square). Sampel yang digunakan dalam penelitian berjumlah 33 responden yang merupakan jumlah staff Relationship Funding Manager PT Bank X di Region Jawa Barat

Funding Relationship Manager merupakan ujung tombak industri perbankan yang dalam jangka panjang memiliki jenjang karir cukup potensial untuk menjadi calon-calon pimpinan wilayah bahkan menjadi seorang grup head maupun jajaran direktur, seperti direktur retail banking. Atas pengalaman tersebut maka perusahaan seharusnya dapat melihat bahwa para karyawan muda yang mengisi jabatan Funding Relationship Manager dapat dipertahankan, dibina dan diberikan pelatihan sebaik mungkin dengan untuk dijadikan calon pemimpin perusahaan. Namun pada kenyataan di lapangan, perbankan mengalami peningkatan turnover yang terus menerus dan tak terkendali untuk posisi jabatan sales.Tingginya tingkat turnover karyawan di PT Bank X ditunjukkan dengan tingginya stres dan rendahnya kepuasan kerja yang dirasakan oleh para karyawan terutama di bagian Funding Relationship Manager.Hasil penelitian menunjukkan bahwa manajemen stres berperan signifikan dalam memoderasi pengaruh stres kerja dan kepuasan kerja terhadap kinerja di PT Bank X. Oleh karena itu, diperlukan peran Divisi Sumber Daya Manusia dan para pemimpin perusahaan untuk dapat merealisasikan peran manajemen stres dalam aktivitas sehari-hari untuk meningkatkan kinerja karyawan.
\end{abstract}

Kata kunci: manajemen stres, kepuasan kerja, kinerja

ABSTRACT

The purpose of this study was to analyze the effect of stress and employee job satisfaction on performance mediated by stress management in PT Bank X West Java Region. This research uses a case study method in the form of a quantitative method by distributing questionnaires and triangulation by means of semi-structured interviews. The data analysis technique used SPSS software with a 90\% confidence level and model testing using the PLS (Partial Least Square) Structural Equation Modeling (SEM). The sample used in the study amounted to 33 respondents who are the number of Relationship Funding Manager staff at PT Bank X West Java Region.

Funding Relationship Manager is the spearhead of the banking industry, which in the long run has a sufficiently potential carrer path to become regional leader candidates and even become a group head or BOD. With this experience, the company should be able to see that young employees who fill the sales position can be maintained, nurtured and given the best possible trainingto become prospective company leaders. However, in reality banks experience a continuous and uncontrollable increase turnover especially for sales position. The high level of employee turnover at PT Bank X is indicated by the high stress and low job satisfaction felt by employees. The results showed that stress management plays a significant role in moderating the effect of job stress and job satisfaction on performance at PT Bank X. Therefore, the role of the Human Resources Division and company leaders is needed to realize the role of stress management in daily activitiesto improve employee performance.

Keywords: stress management, job satisfaction, job performance

\section{PENDAHULUAN}

Perubahan kondisi lingkungan yang dialami oleh sebuah organisasi mendorong organisasi tersebut untuk merespon dengan cepat dan beradaptasi dengan lingkungan pasar yang penuh dengan persaingan.Agar dapat menyesuaikan diri dalam lingkungan persaingan yang semakin hari semakin kompetitif, organisasi 
harus mampu berjalan secara fleksibel. Fleksibilitas organisasi ditentukan oleh sumberdaya yang memiliki kemampuan dan ketrampilan yang tinggi sehingga organisasi memiliki keunggulan kompetitif untuk dapat memenangkan persaingan. Agar dapat melakukan hal tersebut, organisasi harus melakukan evaluasi terhadap sistem kerja maupun kinerja yang selama ini telah berjalan untuk dapat menyesuaikan diri dengan perkembangan ekonomi global dan persaingan digital saat ini.

Saat ini sumber daya manusia dipandang sebagai salah satu faktor terpenting yang mempengaruhi produktivitas dalam suatu organisasi (George \& Zakkariya, 2014). Tujuan organisasi akan sulit terwujud apabila didalamnya tidak ada peran serta manusia meskipun ditunjang dengan peralatan dan mesin yang canggih karena peran manusia sangat dibutuhkan sebagai perencana, pelaksana dan penentu utama terhadap terwujudnya tujuan suatu organisasi.

Untuk mencapai kinerja yang optimal, perusahaan harus dapat memanfaatkan sumber daya (George \& Zakkariya, 2014) yang ada didalamnya termasuk memaksimalkan fungsi sumber daya manusia. Akan tetapi perubahan kondisi lingkungan organisasi ternyata dapat memberikan pengaruh terhadap tingkat stres karyawan yang berdampak pada penurunan kepuasan kerja yang mengarah pada timbulnya keinginan untuk pindah kerja hingga mengakibatkan turnover pada perusahaan (Anjum \& Ming, 2017; Koopmann dkk., 2015; Mirabito \& Berry, 2015).Ditambah dengan sering munculnya kesenjangan antara realita dengan tujuan dan harapan karyawan terhadap perusahaan yang berakibat pada munculnya masalah-masalah yang berhubungan dengan Sumber Daya Manusia (SDM) di dalam perusahaan.

Salah satu industri yang masih menjadikan sumber daya manusia sebagai salah satu aset utama adalah industri perbankan. Keberadaan bank pada era saat ini memiliki peran yang cukup vital (George \& Zakkariya, 2014). Saat ini peran bank dalam industri keuangan bergerak dengan berfokus pada layanan untuk nasabah, berlomba memberikan kenyamanan kepada nasabah mengutamakan service, berinovasi dan memberikan pelayanan dengan cepat (Alferaih, 2015; Kaur \& Kang, 2019; Nandan dkk., 2018; van Gelderen \& Bik, 2016). Selain persaingan teknologi, karyawan bank masih memegang peranan penting terhadap service quality dan service delivery dalam menjembatani interaksi antara bank dengan nasabah (George \& Zakkariya, 2014).

Perkembangan teknologi saat ini sangat berpengaruh besar terhadap carapelayanan industri perbankan. Dimana pada era tahun 1990 hingga tahun 2000 hampir seluruh industri perbankan berlomba-lomba meningkatkan jumlah kantor cabang operasional agar dapat memberikan layanan transaksi nasabah tanpa banyaknya antrian di counter. Namun sejak tiga tahun terakhir seiring perkembangan teknologi digital yang mempermudah transaksi perbankan secara online dan dapat dilakukan tanpa harus antri ke cabang, mengakibatkan kebutuhan kantor cabang operasional semakin berkurang. Untuk dapat melakukan transaksi perbankan, nasabah tidak harus selalu datang ke kantor cabang. Hampir seluruh transaksi perbankan dapat dilakukan dirumah melalui jaringan nirkabel. Sejak transaksi online banking dikembangkan oleh seluruh perusahaan perbankan, maka rata-rata transaksi harian di cabang mengalami penurunan drastis sementara transaksi online banking melesat tajam (Gupta \& Xia, 2018). Fakta di lapangan menunjukkan bahwa hingga 2016 lalu, industri perbankan banyak melakukan pembukaan cabang operasional baru di berbagai daerah.Namun sejak tahun 2017, industri perbankan justru mulai mengurangi cabang operasional dengan mulai menutup sebagian cabang.

PT Bank $X$ merupakan bank swasta terbesar ke-9 di Indonesia yang berdiri sejak lebih dari 60 tahun lalu danmempekerjakan 28,000 karyawan. Saat ini PT Bank X memiliki asset dana kelolaan sebesar IDR 200 Triliun dengan didukung oleh lebih dari 464 jaringan kantor cabang konvensional yang tersebar di 34 provinsi di Indonesia. Dengan tersebarnya kantor operasional PT Bank X dari Aceh hingga Papua maka manajemen membagi wilayah operasional cabang menjadi 12 region dan masing-masing 
region berada dibawah komando seorang Region Head.

PT Bank X merupakan salah satu bank nasional dengan posisi aset berada di urutan 10 besar skala nasional.PT Bank $\mathrm{X}$ saat ini turut mengikuti perkembangan teknologi dan layanan produk di bidang Wealth Management dengan tujuan meningkatkan pendapatan berbasis biaya. Salah satu langkah dan strategi yang dilakukan oleh PT Bank X adalah dengan membentuk divisi Consumer Banking yang didalamnya terdapat posisi Funding Relationship Manager sebagai ujung tombak keberhasilan perusahaan dalam menjaring pendapatan dari Fee Base Income.

Kantor cabang operasional PT Bank X dipimpin oleh seorang Kepala Cabang.Kepala cabang tersebut membawahi 2 tim yaitu tim service dan tim sales. Tim service dikepalai oleh seorang supervisor yaitu Branch Service Manager (BSM).BSM membawahi beberapa orang Customer Service dan beberapa orang Teller.Tim sales atau Relationship Manager dibagi menjadi 2 bagian yaitu Relationship Manager (RM) Lending dan Relationship Manager (RM) Funding. RM Lending memiliki tugas utama untuk mencari nasabah debitur atau peminjam dana dengan memberikan kredit perbankan. Sedangkan RM Funding memiliki tugas utama mencapai target produk pendanaan. Jabatan RM Lending di PT Bank X disebut dengan Business Relationship Manager sedangkan jabatan RM Funding dikenal dengan nama Funding Relationship Manager.

\section{Funding Relationship Manager}

merupakan staf yang ditempatkan disetiap cabang untuk mengelola dana nasabah agar selalu meningkat dan bertumbuh. Semakin erat hubungan antara staf Funding Relationship Manager dengan nasabah maka kepercayaan nasabah terhadap bank semakin meningkat.Dengan demikian, nasabah akan merasa nyaman menyimpan dana di bank tersebut dan berpotensi menambahkan dana kelolaannya untuk dikelola oleh Funding Relationship Manager tersebut. Semakin meningkat pertumbuhan Dana Pihak Ketiga (DPK) nasabah pada sebuah cabang dapat mengindikasikan bahwa cabang tersebut semakin baik kinerjanya (Paais, 2018).
Seorang staf Funding Relationship Manager diharapkan untuk dapat mencapai target dengan mampu menjual seluruh produk yang dimiliki oleh perusahaan kepada para nasabah. Perusahaan menuntut setiap staf yang menduduki jabatan Funding Relationship Manager untuk selalu meningkatkan product knowledge dari setiap produk yang tersedia, memiliki kemampuan dalam menangani setiap keluhan nasabah yang berkaitan dengan simpanannya, memiliki kemampuan untuk menggali kebutuhan nasabah, mengetahui dengan detail bisnis yang dikelola oleh nasabah, dan selalu mengikuti informasi terbarumengenai kondisi perekonomian dan kondisi pasar setiap hari. Beragam tuntutan pekerjaan tersebut tentunya dapat mengakibatkan stres bagi karyawan yang berada pada posisi Funding Relationship Manager.

Funding Relationship Manager merupakan ujung tombak industri perbankan yang dalam jangka panjang memiliki jenjang karir cukup potensial untuk menjadi calon-calon pimpinan wilayah / region head bahkan menjadi seorang grup head maupun jajaran direktur, seperti direktur retail banking. Atas pengalaman tersebut maka perusahaan seharusnya dapat melihat bahwa para karyawan muda yang mengisi jabatan Funding Relationship Manager dapat dipertahankan, dibina dan diberikan pelatihan sebaik mungkin dengan untuk dijadikan calon pemimpin perusahaan. Namun pada kenyataan di lapangan, perbankan mengalami peningkatan turnover yang terus menerus dan tak terkendali untuk posisi jabatan sales (Cheng \& Chang, 2016). Tingginya tingkat turnover karyawan pada industri perbankan di Indonesia mengalami peningkatan sejak 2 tahun terakhir dan dapat dilihat pada Tabel 1 dimana tingkat turnover industri perbankan di Indonesia pada tahun 2018 dan 2019 berada diatas rata-rata industri.

Tabel 1.Tingkat Turnover Rata-rata Industri dan Sektor Jasa Keuangan di Indonesia tahun 2018 dan 2019

\begin{tabular}{|c|c|c|}
\hline Tahun & $\begin{array}{c}\text { Rata-rata } \\
\text { Industri }\end{array}$ & $\begin{array}{c}\text { Industri } \\
\text { Perbankan }\end{array}$ \\
\hline 2018 & $8 \%$ & $12 \%$ \\
\hline 2019 & $7 \%$ & $14 \%$ \\
\hline \multicolumn{3}{|c|}{ Sumber : Mercer Indonesia }
\end{tabular}


Penelitian ini melibatkan variabel stres kerja, kepuasan kerja dan manajemen stres. Penelitian ini bertujuan untuk mengeksplorasi bagaimana variabel independen stres kerja dan kepuasan kerja dapat membentuk variabel dependen kinerja dengan adanya variabel mediator manajemen stres.

\section{KAJIAN TEORI}

\section{Stres Kerja (Work Stress)}

Stres adalah kondisi ketegangan fisik atau mental seseorang yang disebabkan oleh ketidakmampuan seseorang dalam menyesuaikan diri terhadap faktor-faktor yang terjadi di lingkungan sekitar sehingga mengakibatkan ketegangan atau tekanan fisiologis (Chaudhary \& Lodhwal, 2016). Stres secara psikologis didefinisikan sebagai suatu pengalaman yang dirasakan individu ketika menghadapi tuntutan, kendala, dan atau peluang dengan ketidakpastian hasil yang signifikan (Amiruddin, 2018). Mengenali penyebab stres dan gejala-gejala stres sangat penting sehingga setiap orang mampu mengontrol stres yang dialami, terutama stres yang berhubungan dengan pekerjaan seharihari.Perusahaan juga harus berperan seoptimal mungkin dalam membantu karyawan untuk dapat mengontrol stres yang berhubungan dengan pekerjaan sehingga tidak memberikan dampak buruk terhadap produktivitas.

Penelitian tentang stres dan kinerja telah dilakukan berulang kali di banyak negara dan hubungan yang dihasilkan dari penelitian tersebut memberikan hasil yang konsisten (Robbins \& Judge, 2017). Akibat yang dihasilkan dari gejala stres diantaranya adalah penurunan produktivitas, meningkatnya absensi (Ling \& Wong, 2015; Nandan dkk, 2018; Sakr dkk, 2019) dan turnover karyawan (George \& Zakkariya, 2014; Sharma dkk, 2016), perubahan terhadap kebiasaan pola makan, peningkatan terhadap konsumsi alkohol dan rokok, gelisah dan sering mengalami gangguan tidur (Anjum \& Ming, 2017; Srivastava \& Dey, 2019).

\section{Kepuasan Kerja (Job Satisfaction)}

Kepuasan kerja (job satisfaction) adalah suatu perasaan positif (Anjum \& Ming, 2017;
Habeeb, 2019; Jung \& Yoon, 2019; Kunasegaran dkk, 2016) yang dialami karyawan terhadap pekerjaannya, yang dihasilkan dari hasil evaluasi terhadap karakteristik pekerjaannya (Robbins \& Judge, 2017). Sebuah pekerjaan bukan hanya semata-mata menyusun kertas-kertas, menjaga kemanan, merancang kode pemrograman atau mengemudikan mobil.Sebuah pekerjaan membutuhkan interaksi antara seorang atasan dengan team dibawah komandonya, menaati aturan dan kebijakan perusahaan, merumuskan standar kinerja, mampu menghadapi situasi pekerjaan yang biasanya jauh dari kondisi ideal, dan lain-lain. Menurut Andrade \& Westover (Andrade \& Westover, 2019) dalam penelitiannya terhadap para pekerja dari 37 negara berdasarkan data ISSP (International Social Survey Program) menungkapkan bahwa negara dengan tingkat kepuasan kerja tertinggi adalah Venezuela, Austria, Swiss dan Meksiko (Robbins \& Judge, 2017) (p.201). Sedangkan negara dengan tingkat kepuasan terendah adalah Polandia, China dan Jepang. Kepuasan kerja ditandai dengan perasaan positif yang dirasakan seorang karyawan mengenai pekerjaannya berdasarkan evaluasi terhadap karakteristik beban kerja yang dialaminya (Jonasson dkk, 2017).

Indikator kepuasan kerja karyawan terbagi menjadi 5 bagian, yaitu (Robbins \& Judge, 2017):

1. Kepuasan terhadap pekerjaan itu sendiri.

2. Kepuasan terhadap gaji dan tunjangan.

3. Kepuasan terhadap apresiasi dan promosi.

4. Kepuasan terhadap pekerjaan secara keseluruhan

\section{Manajemen Stres (Stress Management)}

Manajemen stres adalah keterampilan seseorang untuk mengantisipasi, mencegah mengeloladan memulihkan diri dari tekanan yang muncul akibat adanya ancaman ketidakmampuan dalam menghadapi masalah (Alferaih, 2015; Smith \& Ascough, 2016; Srivastava \& Dey, 2019; Tagoe \& Amponsah-Tawiah, 2019). Manajemen stres merupakan kemampuan seseorang untuk melakukan perubahan dari stres yang berdampak negatif menjadi stres kerja yang berdampak positif bagi seseorang dan pada akhirnya akan 
menampilkan hasil kerja yang optimal (Hakim \& Sugiyanto, 2017).

Setiap orang pernah merasakan kecemasan dan stres, yang apabila tidak dapat diatasi maka akan menimbulkan masalah bagi mereka pribadi maupun organisasi dimana mereka berada (Anjum \& Ming, 2017; Habeeb, 2019). Stres dapat berupa kecemasan atau ketegangan sarafyang dapat dikelola dengan baik (Corbett, 2014; Dipboye, 2018). Stres dibedakan menjadi 2 jenis yaitu distress (Ahmad \& Afgan, 2016; Kozusznik dkk, 2015; Tagoe \& AmponsahTawiah, 2019) yang berhubungan dengan perasaan negatif yang mengganggu kesehatan dan eustres yang berhubungandengan stres positif yang mendorong kinerja seseorang (George \& Zakkariya, 2014). Salah satu cara untuk mengatasi stres adalah dengan mengadopsi emosi (Connelly \& Torrence, 2018) dan mengubah cara pandang bahwa stres adalah energi yang justru dapat menjadikan fenomena positif untuk lebih produktif (Strutton \& Tran, 2014). Beberapa tekanan emosi diperlukan untuk mendapatkan hasil kinerja yang optimal (Corbett, 2014; Mellifont dkk, 2016)

\section{Kinerja (Performance)}

Kinerja adalah kualitas dan kuantitas pekerjaan yang dihasilkan oleh karyawan dalam suatu periode berdasarkan keterampilan, pengalaman dan keunggulan sesuai tanggung jawab yang diberikan perusahaan kepada setiap individu karyawan (Paais, 2018). Perilaku yang tepat terhadap pekerjaan seringkali menjadi salah satu faktor utama untuk mencapai prestasikerja secara maksimal (Moustaghfir dkk, 2016). Ketika seseorang kurang stimulasi atau tidak termotivasi (Nasr dkk, 2015) maka secara psikologis seseorang tersebut tidak tampil semaksimal mungkin atau sebaliknya justru tampil dengan buruk apabila diberikan tekanan melebihi kemampuan (Corbett, 2014; Sharma dkk., 2016; Srivastava \& Dey, 2019).

Dalam penelitiannya, Ahmad dan Afgan (2016) menemukan korelasi bahwa peningkatan stres kerja dapat mengakibatkan penurunan kinerja. Robbins \& Judge (2017) menyatakan bahwa terdapat hubungan antara stres dengan kinerja.Hubungan tersebut digambarkan dalam pola U-terbalik seperti pada Gambar 1. Dijelaskan bahwa stres dapat menstimulasi tubuh untuk meningkatkan kemampuan dalam memberikan reaksi (Cheng \& Chang, 2016). Seseorang dapat melakukan tugas dengan lebih baik, lebih intens atau lebih cepat ketika ada tekanan (Gong \& Wang, 2019; Nandan dkk, 2018). Namun stres berlebih yang dialami seseorang dapat menjadi kendala sehingga kinerja justru menjadi semakin rendah (Nasr dkk, 2015). Pola U - terbalik ini juga menggambarkan reaksi terhadap stres dalam kurun waktu tertentu.

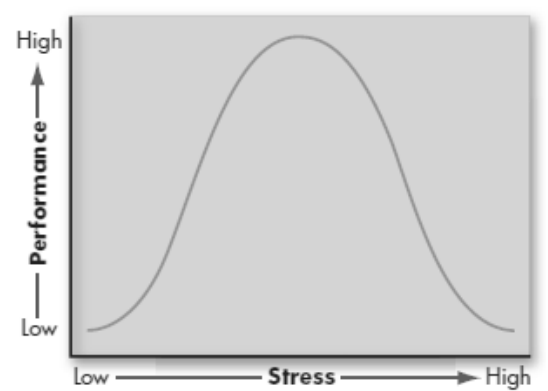

Gambar 1. Hubungan U Terbalik antara Stres dengan Kinerja

Kinerja karyawan dipengaruhi oleh banyak aspek seperti motivasi, lingkungan kerja dan kepemimpinan dalam organisasi (Anjum \& Ming, 2017). Kemampuan seseorang dalam beradaptasi di tempat kerja juga dapat berpengaruh terhadap kinerja individu yang bersangkutan (Jyoti \& Kour, 2017; Kunasegaran dkk, 2016).

\section{METODOLOGI}

\section{Jenis Penelitian}

Penelitian ini menggabungkan metode kuantitatif dalam bentuk penyebaran kuesioner dan triangulasi dengan cara semi-structured interview, dengan melakukan studi kasus pada untuk menjawab hipotesis penelitian di Bank X. Penelitian ini dikategorikan sebagai penelitian mix-method(Clark \& Creswell, 2015). Pemilihan mixed-method pada penelitian ini ditujukan agar diperoleh hasil yang lebih lengkap, reliabel, dan objektif (Clark \& Creswell, 2015; Schoonenboom \& Johnson, 2017) dengan validitas yang tinggi dalam menjawab hipotesis. 


\section{Metode Pengumpulan Data}

Penelitian ini dilakukan di Bank X di Indonesia yang menjadi populasi penelitian. Sampel dalam penelitian ini berupa perusahaan Bank X wilayah Jawa Barat di Indonesia, dengan teknik purposive sampling dengan menetapkan kriteria sampel yang digunakan adalah seluruh karyawan dengan jabatan Funding Relationship Manager di Region Jawa Barat yang tersebar di 33 cabang operasional di 9 kota yang berjumlah 33 orang. Yin (2018) mendefinisikan penelitian dengan menggunakan teknik purposive sampling dimana sampel yang dipilih didasarkan pada karakteristik populasi dan tujuan penelitian (teknik pemilihan non-probabilitas).Penelitian dilakukan dengan menyebarkan kuesioner kepada seluruh team sales di bagian Funding Relationship Manager Region Jawa Barat sejumlah 33 orang.

\section{Sumber Data}

Data yang dikumpulkan dari 33 cabang Bank X di wilayah Jawa Barat merupakan data primer yang diperoleh melalui penyebaran kuesioner. Data kuantitatif yang digunakan berupa kuesioner dengan skala likert berdasarkan lima kategori yaitu: 1 = sangat setuju, 2 = setuju, $3=$ netral/ragu-ragu, $4=$ tidak setuju, dan $5=$ sangat tidak setuju (kuesioner dapat dilihat pada Lampiran 1). Kuesioner dibuat dalam dan disebarkan dalam bentuk "google form". Kuesioner disebarkan kepada 33 karyawan dengan jabatan Funding Relationship Manager yang menjadi responden. Setelah data kuantitatif terkumpul, dilakukan triangulasi sebagai bentuk dari pengumpulan data kualitatif, yang ditujukan kepada professional dan praktisi di bidang perbankan dengan tujuan untuk verifikasi sehingga memperkuat temuan yang diperoleh dari hasil olahan kuesioner (Yin, 2015).

\section{Rancangan Manifest}

Keseluruhan manifest serta indikator yang dirancang menjadi kuesioner pada masing-masing variabel dapat dilihat pada Tabel 2 .

Tabel 2. Rancangan manifest serta indikator masing-masing variabel

\begin{tabular}{|c|c|c|c|c|}
\hline Variabel & Manifest & Indikator & Sumber & Kuesioner \\
\hline \multirow[t]{5}{*}{$\begin{array}{l}\text { 1. Stres } \\
\text { Kerja }\end{array}$} & \multirow[t]{3}{*}{$\begin{array}{ll}\text { 1.1. } & \text { Efek } \\
& \text { Psikologis }\end{array}$} & $\begin{array}{ll}\text { 1.1.1. } & \text { Stres } \\
& \text { (Eustress) }\end{array}$ & $\begin{array}{l}\text { (Berry, 2018; Chou } \\
\text { dkk, 2014; } \\
\text { Schonstrom, 2005) }\end{array}$ & $\begin{array}{l}\text { 1. Karyawan mampu mempertahankan } \\
\text { tingkat energi yang dibutuhkan di } \\
\text { sepanjang hari kerja. } \\
\text { 2. Karyawan merasa pekerjaan yang } \\
\text { dilakukan sehari-hari cukup menantang } \\
\text { dan menyenangkan } \\
\text { 3. Karyawan merasa suasana hati gembira } \\
\text { ketika beraktivitas di kantor. }\end{array}$ \\
\hline & & \begin{tabular}{|ll} 
1.1.2. & Stres \\
& Buruk
\end{tabular} & $\begin{array}{l}\text { (Cheng \& Chang, } \\
\text { 2016; Gong \& } \\
\text { Wang, 2019) }\end{array}$ & $\begin{array}{l}\text { 4. Karyawan merasa tidak cocok dan merasa } \\
\text { jenuh dengan pekerjaannya. }\end{array}$ \\
\hline & & 1.1.3. Iklim Organisasi & $\begin{array}{l}\text { (Aryee dkk, 2015; } \\
\text { Cheng \& Chang, } \\
\text { 2016; Jyoti \& Kour, } \\
\text { 2017; Mirabito \& } \\
\text { Berry, 2015; Tagoe } \\
\text { \& Amponsah- } \\
\text { Tawiah, 2019) }\end{array}$ & $\begin{array}{l}\text { 5. Karyawan merasakan suasana lingkungan } \\
\text { kerja yang nyaman di kantor. } \\
\text { 6. Karyawan merasa budaya kerja di } \\
\text { perusahaan memiliki kualitas yang baik } \\
\text { dan berdampak positif bagi para karyawan. }\end{array}$ \\
\hline & $\begin{array}{l}\text { 1.2. Adaptive } \\
\text { Response }\end{array}$ & 1.2.1. Degree of Feeling & $\begin{array}{l}\text { (Berry, 2018; } \\
\text { Reidolf, 2016; } \\
\text { Schonstrom, 2005; } \\
\text { Utami dkk, 2017) }\end{array}$ & $\begin{array}{l}\text { 7. Karyawan merasa dipercaya dan dianggap } \\
\text { mampu oleh atasan dan manajemen untuk } \\
\text { melaksanakan tugas dan tanggung jawab } \\
\text { sesuai jabatan. } \\
\text { 8. Karyawan merasa memiliki hubungan } \\
\text { yang baik dan saling percayadi dalam tim. }\end{array}$ \\
\hline & $\begin{array}{l}\text { 1.3. Tugas \& } \\
\text { Tanggung } \\
\text { Jawab } \\
\text { (Job } \\
\text { Descriptio } \\
\text { n) }\end{array}$ & 1.3.1. Beban Kerja & $\begin{array}{l}\text { (Alhashmi dkk, } \\
\text { 2017; Garg \& Garg, } \\
\text { 2018; George \& } \\
\text { Zakkariya, 2014; } \\
\text { Koopmann dkk, } \\
\text { 2015; Ling \& Wong, }\end{array}$ & $\begin{array}{l}\text { 9. Karyawan merasa beban kerja yang } \\
\text { diberikan perusahaan sesuai dengan } \\
\text { kapasitas dan kemampuan. } \\
\text { 10. Dalam melaksanakan tugas sehari-hari } \\
\text { karyawan jarang merasa kelelahan. } \\
\text { 11. Karyawan merasa memiliki kondisi badan }\end{array}$ \\
\hline
\end{tabular}




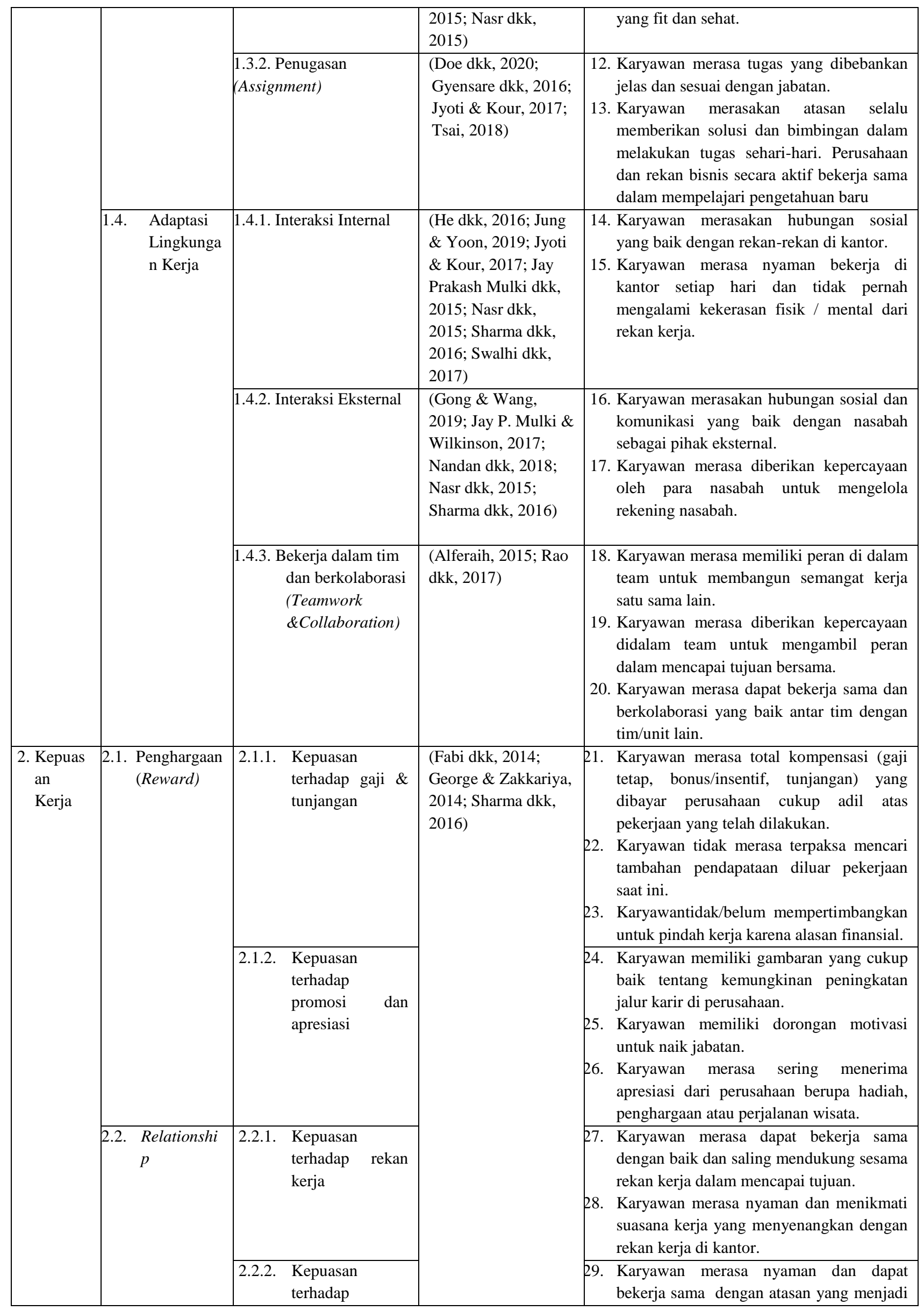




\begin{tabular}{|c|c|c|c|c|}
\hline & & pimpinan & & $\begin{array}{l}\text { pimpinan saat ini. } \\
\text { Karyawan percaya atasan saat ini sangat } \\
\text { mendukung kemajuan karir bawahan. }\end{array}$ \\
\hline & \multirow[t]{2}{*}{ 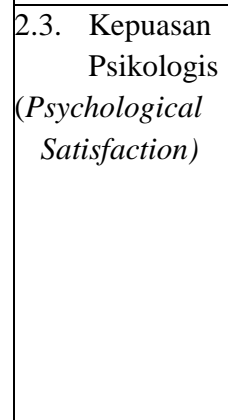 } & $\begin{array}{ll}\text { 2.3.1. } & \text { Kepuasan } \\
& \text { terhadap } \\
& \text { pekerjaan }\end{array}$ & $\begin{array}{l}\text { (Chaudhary \& } \\
\text { Lodhwal, 2016; } \\
\text { George \& Zakkariya, } \\
\text { 2014; Sharma dkk, } \\
\text { 2016) }\end{array}$ & $\begin{array}{l}\text { 31. Karyawan merasa tugas dan tanggung } \\
\text { jawab yang dipercayakan perusahaan } \\
\text { cukup menantang untuk dicapai. } \\
\text { 32. Karyawan memiliki semangat dalam } \\
\text { memberikan kontribusi melampaui apa } \\
\text { yang diwajibkan perusahaan. }\end{array}$ \\
\hline & & $\begin{array}{ll}\text { 2.3.2. } & \text { Kepuasan } \\
& \text { terhadap } \\
& \text { perusahaan }\end{array}$ & $\begin{array}{l}\text { (Aryee dkk, 2015; } \\
\text { Badawy dkk, 2016; } \\
\text { Sahadev dkk, 2016) }\end{array}$ & $\begin{array}{l}\text { 33. Karyawan merasa bangga bekerja di } \\
\text { perusahaan saat ini. } \\
\text { 34. Karyawan merasa diberikan semangat } \\
\text { untuk berusaha lebih baik lagi. }\end{array}$ \\
\hline \multirow[t]{4}{*}{$\begin{array}{l}\text { 3.Manaje- } \\
\text { men } \\
\text { Stres }\end{array}$} & \multirow[t]{2}{*}{ 3.1. Strategi } & $\begin{array}{ll}\text { 3.1.1. } & \text { Manajemen } \\
& \text { Waktu }\end{array}$ & \multirow[t]{2}{*}{$\begin{array}{l}\text { (Aryee dkk, 2015; } \\
\text { Grissom dkk, 2015; } \\
\text { Sarfraz, 2017) }\end{array}$} & $\begin{array}{l}\text { 35. } \begin{array}{l}\text { Karyawan memiliki keleluasaan untuk } \\
\text { mengatur jadwal dalam melakukan } \\
\text { pekerjaan. }\end{array} \\
\text { 36. } \\
\text { Karyawan memiliki jadwal kerja yang } \\
\text { teratur setiap hari sehingga jarang lembur } \\
\text { hingga malam. }\end{array}$ \\
\hline & & \begin{tabular}{|lll}
3.1 .2$. & Perencanaan $\&$ \\
& Penataan & \\
& (Planning & $\&$ \\
& Organizing) &
\end{tabular} & & $\begin{array}{l}\text { 37. Karyawan } \\
\text { memilikiperlengkapan/peralatan/sumber } \\
\text { daya untuk melakukan pekerjaan secara } \\
\text { efektif dan terencana. }\end{array}$ \\
\hline & \multirow[t]{2}{*}{\begin{tabular}{|ll} 
3.2. & Dukungan \\
& Sosial
\end{tabular}} & $\begin{array}{lll}\text { 3.2.1. } & \begin{array}{l}\text { Dukungan dari } \\
\text { pimpinan }\end{array}\end{array}$ & \multirow{2}{*}{$\begin{array}{l}\text { (Jyoti \& Kour, 2017; } \\
\text { Kunasegaran dkk, } \\
\text { 2016; Ling \& Wong, } \\
\text { 2015; Jay Prakash } \\
\text { Mulki dkk, 2015; } \\
\text { Srivastava \& Dey, } \\
\text { 2019; Swalhi dkk, } \\
\text { 2017; van Gelderen } \\
\text { \& Bik, 2016) }\end{array}$} & $\begin{array}{l}\text { 38. Atasan memberikan saran yang berguna } \\
\text { untuk mencari jalan keluar dari setiap } \\
\text { kendala yang dihadapi di lapangan. } \\
\text { 39. Atasan melakukan pengambilan keputusan } \\
\text { yang bijaksana. } \\
\text { 40. Atasan memberikan dorongan dan } \\
\text { semangat kerja yang positif. }\end{array}$ \\
\hline & & \begin{tabular}{|ll} 
3.2.2. & Dukungan \\
& dari \\
& rekan kerja
\end{tabular} & & 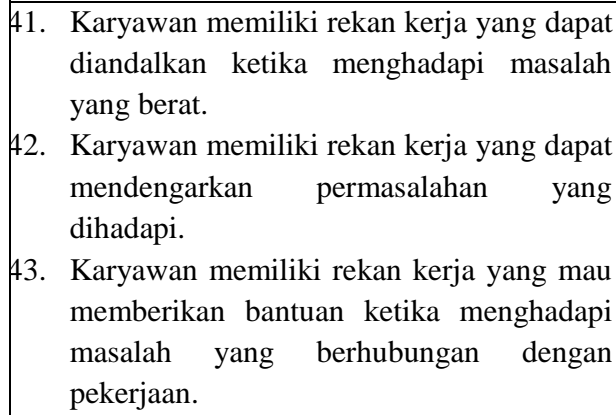 \\
\hline \multirow[t]{2}{*}{$\begin{array}{ll}\text { 4. } & \mathrm{Ki}- \\
& \text { nerja }\end{array}$} & \multirow[t]{2}{*}{ 4.1. Finansial } & $\begin{array}{ll}\text { 4.1.1. } & \text { Key } \\
& \text { Performance } \\
& \text { Indicator }\end{array}$ & $\begin{array}{l}\text { (Badawy dkk, 2016; } \\
\text { Sahadev dkk, 2016) }\end{array}$ & $\begin{array}{l}\text { 44. Karyawan memiliki keinginan dan niat } \\
\text { berusaha untuk dapat mencapai minimal } \\
70 \% \text { dari target bulanan yang sudah } \\
\text { ditetapkan perusahaan. } \\
\text { 45. Kinerja pekerjaan karyawan dievaluasi } \\
\text { dengan sangat adil. }\end{array}$ \\
\hline & & 4.1.2. Absensi & $\begin{array}{l}\text { (Anjum \& Ming, } \\
\text { 2017; George \& } \\
\text { Zakkariya, 2014; } \\
\text { Ling \& Wong, 2015; } \\
\text { Sakr dkk, 2019; } \\
\text { Sharma dkk, 2016) }\end{array}$ & 46. Karyawan jarang absen bekerja. \\
\hline
\end{tabular}

\section{Teknik Analisis Data}

Pengujian hipotesis dilakukan pada keempat variabel yang diteliti dan terdapat dua tahapan dalam pengolahan data pada penelitian
ini.Tahapan pertama adalah mengumpulkan hasil kuesioner kemudian dilakukan uji validitas dan uji reabilitas menggunakan software SPSS, dengan tingkat kepercayaan 90\%. Selanjutnya dilakukan 
pengujian model menggunakan Structural Equation Modelling (SEM) jenis PLS (Partial Least Square) dikarenakan jumlah sampel kurang dari seratus (100) dalam penelitian ini.

Tahap kedua adalah konfirmasi data dengan melakukan perbandingan antara hasil hipotesis dengan triangulasi kepada karyawan dan pimpinan senior perusahaan dengan skema semistructured interview. Tujuan dilakukannya konfirmasi adalah untuk memperkuat validitas dari hasil temuan pengolahan data dan untuk memberikan masukan bagi perusahaan.

Tahapan dalam pengolahan data kuesioner dilakukan dengan uji validitas, uji reliabilitas dan uji hipotesis. Setiap pertanyaan kuesioner dinyatakan valid jika nilai $r$ hitung lebih besar $r$ tabel dan reliable jikanilai Cronbach Alpha diatas 0,7. Dalam penelitian dengan total responden sebanyak 33 orang maka ditetapkan $r$ tabel yang digunakan adalah 0,2913 dengan tingkat kepercayaan 90\% menggunakan software SPSS (Statistical Package for the Social Sciences). Penentuan tingkat kepercayaan ini dilakukan dengan mempertimbangkan bahwa preferensi manusia yang dinamis dan studi literatur.

Tahap lanjutan setelah uji validitas, reliabilitas, dan hipotesis adalah uji model Structural Equation Modelling (SEM)SmartPLS. Uji model dalam penelitian ini menggunakan program perangkat lunak SmartPLS dengan mempertimbangkan perangkat ini cukup komprehensif untuk melakukan analisis SEM untuk uji model statistik (Sarstedt \& Cheah, 2019). Pengujian terhadap model dengan menggunakan analisis SEM SmartPLS dilakukan dalam 2 (dua) tahap evaluasi yaitu outer model dan inner model. Evaluasi outer model dilakukan dengan menguji validitas konvergen, reliabilitas konsistensi internal, dan reliabilitas indikator.

Setiap indikator harus memenuhi 3 kriteria pengujian outer model yaitu convergent validity, Average Variance Extracted (AVE) dan composite reliability dengan detail berikut ini (Bewick dkk, 2003) :

(1) validitas konvergen dengan syarat AVE $>0,5$

(2) reliabilitas konsistensi internal dengan syarat komposit reliabilitas $>0,7$
(3) reliabilitas indikator dengan syarat faktor loading $>0,5$

Selanjutnya dilakukan pengujian inner model dengan melihat effect sizedari setiap variable. Kriteria penentuan efek dari variabel independen terhadap dependen adalah hubungan effect size sebagai berikut (Wong, 2013) :

(1) $0,02-0,14$ adalah kecil

(2) 0,15-0,35 adalah menengah

(3) >0,35 adalah besar

Ketiga kriteria efek tersebut digunakan untuk mendukung hasil uji hipotesis setelah mempertimbangkan tingkat signifikansi dan nilai $\mathrm{t}$ stat. Selain itu, dilihat juga pengaruh masingmasing variabel independent terhadap variabel dependen yang ditentukan dari nilai $R$ Square.Semakin besar $R$ Square maka semakin besar variasi dalam variabel dependen yang dapat dijelaskan oleh variabel independen.

\section{OperasionalisasiVariabel}

Penelitian ini melibatkan variabel stres kerja, kepuasan kerja dan manajemen stres.Penelitian ini bertujuan untuk mengeksplorasi bagaimana variabel independen stres kerja dan kepuasan kerja dapat membentuk variabel dependen kinerja dengan adanya variabel mediator manajemen stres.Berdasarkan studi literatur yang telah dilakukan maka model penelitian dapat dilihat pada Gambar 2.

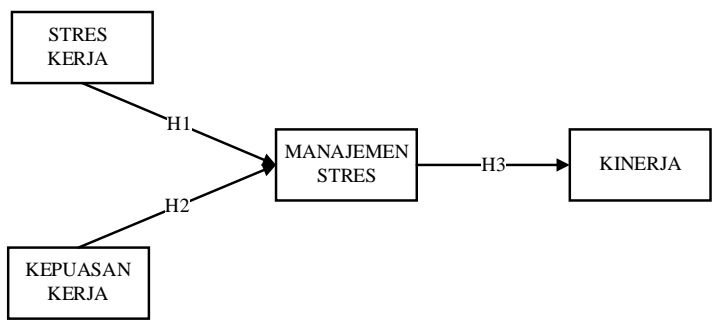

Gambar 2. Model Penelitian

Keterangan :

H1 : stres kerja berpengaruh signifikan terhadap manajemen stres

$\mathrm{H} 2$ : kepuasan kerja berpengaruh signifikan terhadap manajemen stres

H3 : manajemen stres memediasi pengaruh stres kerja dan kepuasan kerja terhadap kinerja 
Operasionalisasi variabel yang terdapat pada penelitian ini dijelaskan dalam tabel sebagai berikut :

\begin{tabular}{|c|c|c|}
\hline \multicolumn{3}{|c|}{ Tabel 3.OperasionalisasiVariabel } \\
\hline Variabel & Manifest & Indikator \\
\hline \multirow{4}{*}{ Stress kerja } & \multirow{3}{*}{$\begin{array}{c}\text { Efek } \\
\text { Psikologis }\end{array}$} & Stress baik \\
\hline & & Stress buruk \\
\hline & & Iklim organisasi \\
\hline & $\begin{array}{l}\text { Adaptive } \\
\text { Response }\end{array}$ & Degree offeelings \\
\hline \multirow{5}{*}{ Stress kerja } & \multirow{2}{*}{$\begin{array}{l}\text { Tugas \& } \\
\text { Tanggung } \\
\text { jawab }\end{array}$} & Beban kerja \\
\hline & & Penugasan \\
\hline & \multirow{3}{*}{$\begin{array}{c}\text { Adaptasi } \\
\text { Lingkungan } \\
\text { Kerja }\end{array}$} & Internal \\
\hline & & Eksternal \\
\hline & & Bekerja dalam tim \\
\hline \multirow{6}{*}{$\begin{array}{l}\text { Kepuasan } \\
\text { kerja }\end{array}$} & \multirow{2}{*}{ Penghargaan } & $\begin{array}{l}\text { Kepuasan terhadap gaji } \\
\text { dan tunjangan }\end{array}$ \\
\hline & & $\begin{array}{l}\text { Kepuasan terhadap } \\
\text { promosi dan apresiasi }\end{array}$ \\
\hline & \multirow{2}{*}{ Relationship } & $\begin{array}{l}\text { Kepuasan terhadap rekan } \\
\text { kerja }\end{array}$ \\
\hline & & $\begin{array}{l}\text { Kepuasan terhadap } \\
\text { pimpinan }\end{array}$ \\
\hline & \multirow{2}{*}{$\begin{array}{l}\text { Kepuasan } \\
\text { psikologis }\end{array}$} & $\begin{array}{l}\text { Kepuasan terhadap } \\
\text { pekerjaan }\end{array}$ \\
\hline & & $\begin{array}{l}\text { Kepuasan terhadap } \\
\text { perusahaan }\end{array}$ \\
\hline \multirow{4}{*}{$\begin{array}{l}\text { Manajemen } \\
\text { stress }\end{array}$} & \multirow{2}{*}{ Strategi } & Manajemen waktu \\
\hline & & Perencanaan \& penataan \\
\hline & \multirow{2}{*}{$\begin{array}{l}\text { Dukungan } \\
\text { sosial }\end{array}$} & Dukungan pimpinan \\
\hline & & Dukungan rekan kerja \\
\hline \multirow[t]{2}{*}{ Kinerja } & Finansial & $\begin{array}{l}\text { Key Performance } \\
\text { Indicator }\end{array}$ \\
\hline & Non Finansial & Absensi \\
\hline
\end{tabular}

Sumber : Pengolahan Data

\section{PEMBAHASAN DAN HASIL PENELITIAN}

\section{Profil PT Bank X}

Didirikan pada tahun 1956, PT Bank X merupakan salah satu lembaga keuangan terbesar di Indonesia, dengan jaringan tersebar di wilayah Aceh hingga Papua. Per 31 Desember 2019, Bank $\mathrm{X}$ mencatatkan aset sebesar Rp203 triliun, didukung 856 kantor cabang dan pusat pelayanan, terdiri dari kantor cabang konvensional, unit Bank X Simpan Pinjam, unit Syariah, serta kantor cabang anak perusahaan. Bank $\mathrm{X}$ menyediakan akses ke 1.454 ATM dan 70 CDM, serta puluhan ribu ATM melalui kerja sama dengan jaringan ATM Bersama, ALTO, dan Prima yang tersebar di 34 provinsi di Indonesia.
Sejalan dengan visi perusahaan yaitu "Peduli dan Membantu Jutaan Orang Mencapai kesejahteraan," PT Bank X terus berupaya meningkatkan pertumbuhan ekonomi di semua segmen usahanya melalui jaringan distribusi PT Bank X di Indonesia. PT Bank X mengembangkan beragam bisnis perbankan, meliputi perbankan usaha kecil dan menengah (UKM), perbankan komersial, perbankan korporasi, perbankan ritel, perbankan konsumer, perbankan mikro melalui Bank X Simpan Pinjam, pembiayaan perdagangan (trade finance), manajemen kas (cash management), layanan valuta asing dan produk treasury serta pasar modal, layanan lembaga keuangan serta perbankan syariah. Selain itu, PT Bank X juga menyediakan pembiayaan otomotif dan barangbarang konsumen melalui X Finance.

PT Bank X senantiasa meningkatkan produk, layanan serta penjualan silang (cross-sell) kepada nasabah dalam memperkuat hubungan dengan nasabah. Pada tahun 2015, PT Bank X meluncurkan layanan pembayaran e-commerce atau transaksi belanja online melalui Bank $X$ Online Banking, seiring meningkatnya transaksi berbelanja melalui internet yang telah menjadi kebutuhan dan gaya hidup masyarakat.

PT Bank X dan anak perusahaan memiliki total jumlah karyawan sejumlah 50.226 orang, terdiri dari 36.653 orang karyawan berjenis kelamin pria dan 13.573 orang karyawan berjenis kelamin wanita. Berdasarkan status kepegawaian, PT Bank X mempekerjakan karyawan permanen sejumlah 35.606 orang dan karyawan non permanen sejumlah 14.620 orang. Sedangkan berdasarkan masa kerjanya, karyawan yang telah memiliki masa kerja diatas 20 tahun sejumlah 1.429 orang, masa kerja 10 hingga 20 tahun sejumlah 7.450 orang, masa kerja 5 hingga 10 tahun sejumlah 12.576 orang, masa kerja 3 hingga 5 tahun sejumlah 10.391 orang dan karyawan dengan masa kerja 0 hingga 3 tahun sebanyak 18.380 orang.

Berdasarkan tingkat pendidikan, jumlah karyawan PT Bank X dengan tingkat pendidikan Pasca Sarjana sebanyak 445 orang, karyawan dengan tingkat pendidikan Sarjana sejumlah 31.963 orang, karyawan dengan tingkat 
pendidikan Diploma sejumlah 9.719 orang, karyawan dengan tingkat pendidikan SLTA sejumlah 8.065 orang dan karyawan dengan tingkat pendidikan SLTP/SD adalah sejumlah 34 orang.Sedangkan dari komposisi usia, jumlah karyawan yang berada pada usia kurang dari 25 tahun adalah sejumlah 4.655 orang, usia 25 - 34 tahun sejumlah 29.616 orang, usia 35 - 44 tahun sejumlah 12.996 orang, dan karyawan dengan usia 45 tahun keatas sejumlah 2.959 orang. Sedangkan demografi responden yang bekerja di Region Jawa Barat dapat dilihat pada tabel 4.

\begin{tabular}{|l|c|c|}
\hline \multicolumn{2}{|c|}{ Tabel 4.Demografi Responden } \\
\hline Demografi responden (n= 33) \\
\hline Keterangan & $\mathrm{n}$ & $\%$ \\
\hline Lokasi Kerja & & \\
\hline Bandung & 26 & $78,79 \%$ \\
\hline Di luar Bandung & 7 & $21,21 \%$ \\
\hline Masa kerja & & \\
\hline < 3 tahun & 4 & $12,12 \%$ \\
\hline $3-5$ tahun & 16 & $48,48 \%$ \\
\hline 5-10 tahun & 11 & $33,33 \%$ \\
\hline$>10$ tahun & 2 & $6,06 \%$ \\
\hline Level Jabatan & & \\
\hline Officer & 9 & $27,27 \%$ \\
\hline Supervisor & 11 & $33,33 \%$ \\
\hline Manager & 9 & $27,27 \%$ \\
\hline Senior Manager & 4 & $12,12 \%$ \\
\hline Jenis Kelamin & & \\
\hline Pria & 11 & $33,33 \%$ \\
\hline Wanita & 22 & $66,67 \%$ \\
\hline Usia & & \\
\hline < 25 tahun & 6 & $18,18 \%$ \\
\hline 25 - 34 tahun & 19 & $57,58 \%$ \\
\hline 35 - 45 tahun & 5 & $15,15 \%$ \\
\hline$>45$ tahun & 3 & $9,09 \%$ \\
\hline
\end{tabular}

\section{Hasil Uji Validitas dan Reliabilitas}

Dalam penelitian dengan total responden sebanyak 33 orang maka ditetapkan $r$ tabel yang digunakan adalah 0,2913. Berdasarkan hasil pengujian data, dapat disimpulkan bahwa seluruh variabel yang digunakan dalam penelitian ini dinyatakan valid karena memiliki $r$ hitung yang lebih besar dari $\mathrm{r}$ tabel.Hasil uji validitas dapat dilihat pada tabel 5 dan tabel 6 .

Tabel 5.Hasil Uji Validitas

\begin{tabular}{|c|c|c|c|c|c|}
\hline & $\begin{array}{c}\mathbf{r} \\
\text { tabel }\end{array}$ & $\begin{array}{c}\mathbf{r} \\
\text { hitung }\end{array}$ & sig. & $\begin{array}{c}\text { sig. } \\
(\mathbf{2} \text { tailed })\end{array}$ & Validitas \\
\hline sk1 & 0,2913 & 0,695 & 0,10 & 0,000 & Valid \\
\hline sk2 & 0,2913 & 0,732 & 0,10 & 0,000 & Valid \\
\hline sk3 & 0,2913 & 0,678 & 0,10 & 0,000 & Valid \\
\hline sk4 & 0,2913 & 0,664 & 0,10 & 0,008 & Valid \\
\hline sk5 & 0,2913 & 0,696 & 0,10 & 0,000 & Valid \\
\hline sk6 & 0,2913 & 0,687 & 0,10 & 0,016 & Valid \\
\hline sk7 & 0,2913 & 0,779 & 0,10 & 0,000 & Valid \\
\hline
\end{tabular}

Tabel 6.Hasil Uji Validitas (Lanjutan)

\begin{tabular}{|c|c|c|c|c|c|}
\hline & $r$ tabel & $\begin{array}{c}\mathbf{r} \\
\text { hitung }\end{array}$ & sig. & $\begin{array}{l}\text { sig. (2 } \\
\text { tailed) }\end{array}$ & Validitas \\
\hline sk8 & 0,2913 & 0,710 & 0,10 & 0,000 & Valid \\
\hline sk9 & 0,2913 & 0,785 & 0,10 & 0,000 & Valid \\
\hline sk10 & 0,2913 & 0,590 & 0,10 & 0,000 & Valid \\
\hline sk11 & 0,2913 & 0,811 & 0,10 & 0,000 & Valid \\
\hline sk12 & 0,2913 & 0,688 & 0,10 & 0,000 & Valid \\
\hline sk13 & 0,2913 & 0,705 & 0,10 & 0,000 & Valid \\
\hline sk14 & 0,2913 & 0,674 & 0,10 & 0,000 & Valid \\
\hline sk15 & 0,2913 & 0,585 & 0,10 & 0,000 & Valid \\
\hline sk16 & 0,2913 & 0,753 & 0,10 & 0,000 & Valid \\
\hline sk17 & 0,2913 & 0,635 & 0,10 & 0,000 & Valid \\
\hline sk18 & 0,2913 & 0,763 & 0,10 & 0,000 & Valid \\
\hline sk19 & 0,2913 & 0,688 & 0,10 & 0,000 & Valid \\
\hline sk20 & 0,2913 & 0,853 & 0,10 & 0,000 & Valid \\
\hline ms1 & 0,2913 & 0,709 & 0,10 & 0,000 & Valid \\
\hline ms2 & 0,2913 & 0,660 & 0,10 & 0,000 & Valid \\
\hline ms3 & 0,2913 & 0,726 & 0,10 & 0,003 & Valid \\
\hline ms4 & 0,2913 & 0,828 & 0,10 & 0,000 & Valid \\
\hline ms5 & 0,2913 & 0,851 & 0,10 & 0,000 & Valid \\
\hline ms6 & 0,2913 & 0,877 & 0,10 & 0,000 & Valid \\
\hline ms7 & 0,2913 & 0,744 & 0,10 & 0,000 & Valid \\
\hline ms8 & 0,2913 & 0,560 & 0,10 & 0,000 & Valid \\
\hline ms9 & 0,2913 & 0,817 & 0,10 & 0,001 & Valid \\
\hline kk1 & 0,2913 & 0,715 & 0,10 & 0,000 & Valid \\
\hline kk2 & 0,2913 & 0,636 & 0,10 & 0,000 & Valid \\
\hline kk3 & 0,2913 & 0,668 & 0,10 & 0,000 & Valid \\
\hline $\mathbf{k k 4}$ & 0,2913 & 0,818 & 0,10 & 0,000 & Valid \\
\hline kk5 & 0,2913 & 0,662 & 0,10 & 0,000 & Valid \\
\hline kk6 & 0,2913 & 0,738 & 0,10 & 0,000 & Valid \\
\hline kk7 & 0,2913 & 0,650 & 0,10 & 0,000 & Valid \\
\hline kk8 & 0,2913 & 0,741 & 0,10 & 0,000 & Valid \\
\hline kk9 & 0,2913 & 0,756 & 0,10 & 0,000 & Valid \\
\hline
\end{tabular}




\begin{tabular}{|c|c|c|c|c|c|} 
kk10 & 0,2913 & 0,697 & 0,10 & 0,000 & Valid \\
\hline kk11 & 0,2913 & 0,820 & 0,10 & 0,000 & Valid \\
\hline kk12 & 0,2913 & 0,794 & 0,10 & 0,000 & Valid \\
\hline kk13 & 0,2913 & 0,697 & 0,10 & 0,000 & Valid \\
\hline kk14 & 0,2913 & 0,796 & 0,10 & 0,000 & Valid \\
\hline kin1 & 0,2913 & 0,856 & 0,10 & 0,000 & Valid \\
\hline kin2 & 0,2913 & 0,858 & 0,10 & 0,000 & Valid \\
\hline kin3 & 0,2913 & 0,694 & 0,10 & 0,000 & Valid \\
\hline \multicolumn{7}{|c|}{$5 u m b e r:$ Pengolahan Data } \\
\hline
\end{tabular}

Tabel 8.Hasil Uji Faktor Loading

Keterangan :

sk $=$ stres kerja

$\mathrm{ms}=$ manajemen stres

$\mathrm{kk}=$ kepuasan kerja

kin $=$ kinerja

Pengujian berikutnya adalah pengujian reliabilitas.Untuk menilai tingkat reliabilitas variabel yang digunakan pada penelitian ini dilihat berdasarkan rekapitulasi nilai Cronbach Alpha.

Berdasarkan rekapitulasi nilai Cronbach Alpha pada tabel 7, diketahui bahwa nilai Cronbach Alpha untuk masing-masing variabel adalah lebih besar dari 0,700 (Bewick dkk, 2003) sehingga dapat disimpulkan bahwa seluruh instrumen yang digunakan dalam penelitian ini telah memenuhi uji reliabilitas.

Tabel 7.Hasil Uji Reliabilitas

\begin{tabular}{|c|c|c|c|}
\hline Variabel & $\begin{array}{c}\text { Min. } \\
\text { Cronbrach } \\
\text { Alpha }\end{array}$ & $\begin{array}{c}\text { Cronbrach } \\
\text { Alpha }\end{array}$ & Reliabilitas \\
\hline $\mathbf{s k}$ & 0,700 & 0,948 & Reliabel \\
\hline $\mathbf{m s}$ & 0,700 & 0,906 & Reliabel \\
\hline $\mathbf{k k}$ & 0,700 & 0,933 & Reliabel \\
\hline $\mathbf{k i n}$ & 0,700 & 0,728 & Reliabel \\
\hline \multicolumn{4}{|c|}{ Syarat reliabilitas : Cronbach Alpha $>0,7$} \\
\hline
\end{tabular}

\section{Evaluasi Outer Model}

Evaluasi outer model dilakukan dengan menguji validitas konvergen, reliabilitas konsistensi internal, dan reliabilitas indikator. Uji model dalam penelitian ini (seperti digambarkan pada gambar 3) menggunakan program perangkat lunak SmartPLS dengan mempertimbangkan perangkat ini cukup komprehensif untuk melakukan analisis SEM untuk uji model statistik (Sarstedt \& Cheah, 2019). Hasil uji tersebut dapat dilihat pada tabel 8 di bawah ini :

\begin{tabular}{|c|c|c|c|c|c|}
\hline 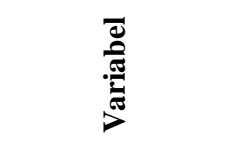 & 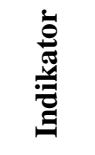 & 章 & 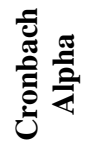 & 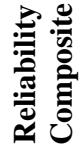 & $\frac{1}{2}$ \\
\hline \multirow{20}{*}{ Stres Kerja } & SK1 & 0,690 & \multirow{20}{*}{0,948} & \multirow{20}{*}{0,953} & \multirow{20}{*}{0,508} \\
\hline & SK2 & 0,743 & & & \\
\hline & SK3 & 0,669 & & & \\
\hline & SK4 & 0,639 & & & \\
\hline & SK5 & 0,679 & & & \\
\hline & SK6 & 0,670 & & & \\
\hline & SK7 & 0,766 & & & \\
\hline & SK8 & 0,709 & & & \\
\hline & SK9 & 0,775 & & & \\
\hline & SK10 & 0,579 & & & \\
\hline & SK11 & 0,816 & & & \\
\hline & SK12 & 0,695 & & & \\
\hline & SK13 & 0,687 & & & \\
\hline & SK14 & 0,701 & & & \\
\hline & SK15 & 0,602 & & & \\
\hline & SK16 & 0,773 & & & \\
\hline & SK17 & 0,655 & & & \\
\hline & SK18 & 0,786 & & & \\
\hline & SK19 & 0,711 & & & \\
\hline & SK20 & 0,847 & & & \\
\hline \multirow{9}{*}{$\begin{array}{l}\text { Manajemen } \\
\text { Stress }\end{array}$} & MS1 & 0,763 & \multirow{9}{*}{0,918} & \multirow{9}{*}{0,924} & \multirow{9}{*}{0,579} \\
\hline & MS2 & 0,605 & & & \\
\hline & MS3 & 0,701 & & & \\
\hline & MS4 & 0,844 & & & \\
\hline & MS5 & 0,881 & & & \\
\hline & MS6 & 0,901 & & & \\
\hline & MS7 & 0,748 & & & \\
\hline & MS8 & 0,535 & & & \\
\hline & MS9 & 0,791 & & & \\
\hline \multirow{10}{*}{ Kepuasan Kerja } & KK1 & 0,690 & \multirow{10}{*}{0,933} & \multirow{10}{*}{0,942} & \multirow{10}{*}{0,541} \\
\hline & KK2 & 0,565 & & & \\
\hline & KK3 & 0,658 & & & \\
\hline & KK4 & 0,836 & & & \\
\hline & KK5 & 0,625 & & & \\
\hline & KK6 & 0,741 & & & \\
\hline & KK7 & 0,670 & & & \\
\hline & KK8 & 0,771 & & & \\
\hline & KK9 & 0,784 & & & \\
\hline & KK10 & 0,724 & & & \\
\hline
\end{tabular}




\begin{tabular}{|c|c|c|c|c|c|}
\hline & KK11 & 0,844 & & & \\
\hline & KK12 & 0,795 & & & \\
\hline & KK13 & 0,711 & & & \\
\hline & KK14 & 0,816 & & & \\
\hline \multirow{3}{*}{ Kinerja } & KIN1 & 0,835 & \multirow{3}{*}{0,728} & \multirow{3}{*}{0,848} & \multirow{3}{*}{0,653} \\
\hline & KIN2 & 0,900 & & & \\
\hline & KIN3 & 0,672 & & & \\
\hline
\end{tabular}

\section{Evaluasi Model Struktural (Inner Model)}

Dilakukan pengujian inner model dengan melihat effect size yang dapat dilihat pada Tabel 10. Kriteria penentuan efek dari variabel independen terhadap dependen adalah hubungan effect size sebagai berikut (Wong, 2013):

(1) $0,02-0,14$ adalah kecil

(2) $0,15-0,35$ adalah menengah
(3) $>0,35$ adalah besar

Ketiga kriteria efek tersebut digunakan untuk mendukung hasil uji hipotesis setelah mempertimbangkan tingkat signifikansi dan nilai t stat. Selain itu, dilihat juga pengaruh masingmasing variabel independent terhadap variabel dependen yang ditentukan dari nilai $R$ Square.Semakin besar $R$ Square maka semakin besar variasi dalam variabel dependen yang dapat dijelaskan oleh variabel independen.

Hasil pengolahan kuesioner dapat dilihat pada Tabel 8 dengan didasarkan pada perhitungan persentase kuesioner dari responden yang menyatakan setuju (jawaban pada skala Likert 4 dan 5) sehingga diperoleh persentase dari masingmasing manifest.

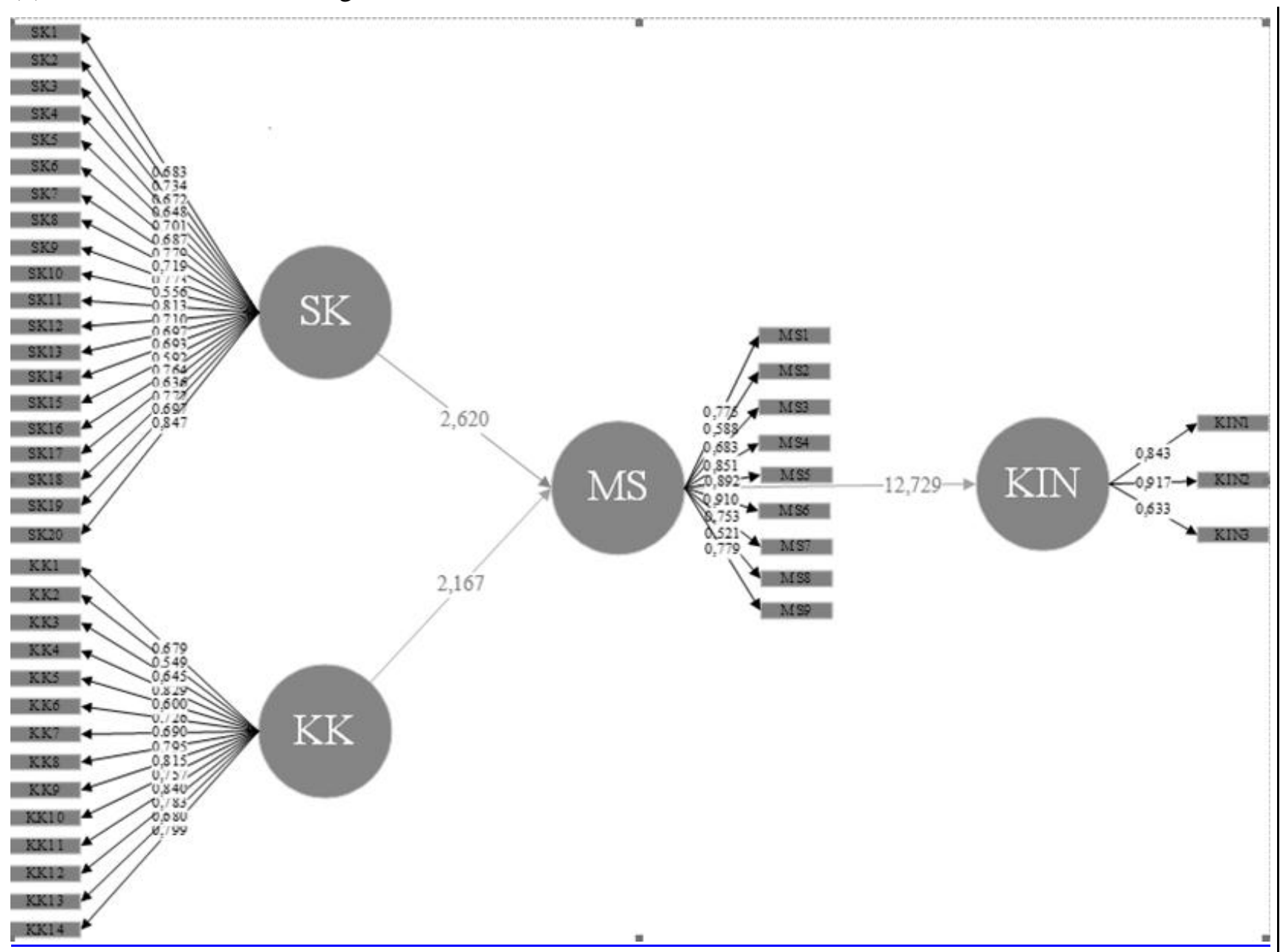

Gambar 3.Pengujian Model 
Tabel 9.Pengolahan Hasil Kuesioner

\begin{tabular}{|c|c|c|c|}
\hline & Manifest & Indikator & $\begin{array}{c}\text { Persent } \\
\text { ase }\end{array}$ \\
\hline \multirow{9}{*}{$\begin{array}{l}\text { Stress } \\
\text { kerja }\end{array}$} & \multirow{3}{*}{$\begin{array}{l}\text { Efek } \\
\text { Psikologis }\end{array}$} & Stress baik & $45,96 \%$ \\
\hline & & Stress buruk & $10,10 \%$ \\
\hline & & Iklim organisasi & $29,80 \%$ \\
\hline & $\begin{array}{l}\text { Adaptive } \\
\text { Response }\end{array}$ & $\begin{array}{l}\text { Degree of } \\
\text { feelings }\end{array}$ & $83,33 \%$ \\
\hline & \multirow{2}{*}{$\begin{array}{l}\text { Tugas \& } \\
\text { Tanggung } \\
\text { jawab }\end{array}$} & Beban kerja & $48,48 \%$ \\
\hline & & Penugasan & $33,33 \%$ \\
\hline & \multirow{3}{*}{$\begin{array}{l}\text { Adaptasi } \\
\text { Lingkungan } \\
\text { Kerja }\end{array}$} & Internal & $27,27 \%$ \\
\hline & & Eksternal & $25,97 \%$ \\
\hline & & $\begin{array}{l}\text { Bekerja dalam } \\
\text { tim }\end{array}$ & $36,36 \%$ \\
\hline \multirow{6}{*}{$\begin{array}{l}\text { Kepuasan } \\
\text { kerja }\end{array}$} & \multirow{2}{*}{$\begin{array}{l}\text { Penghargaa } \\
n\end{array}$} & $\begin{array}{l}\text { Kepuasan } \\
\text { terhadap gaji } \\
\text { dan tunjangan }\end{array}$ & $38,38 \%$ \\
\hline & & $\begin{array}{l}\text { Kepuasan } \\
\text { terhadap } \\
\text { promosi dan } \\
\text { apresiasi }\end{array}$ & $42,93 \%$ \\
\hline & \multirow{2}{*}{ Relationship } & $\begin{array}{l}\text { Kepuasan } \\
\text { terhadap rekan } \\
\text { kerja }\end{array}$ & $40,91 \%$ \\
\hline & & $\begin{array}{l}\text { Kepuasan } \\
\text { terhadap } \\
\text { pimpinan }\end{array}$ & $40,15 \%$ \\
\hline & \multirow{2}{*}{$\begin{array}{l}\text { Kepuasan } \\
\text { psikologis }\end{array}$} & $\begin{array}{l}\text { Kepuasan } \\
\text { terhadap } \\
\text { pekerjaan }\end{array}$ & $34,09 \%$ \\
\hline & & $\begin{array}{l}\text { Kepuasan } \\
\text { terhadap } \\
\text { perusahaan }\end{array}$ & $40,15 \%$ \\
\hline \multirow{4}{*}{$\begin{array}{c}\text { Manajeme } \\
\text { n stress }\end{array}$} & \multirow{2}{*}{ Strategi } & $\begin{array}{l}\text { Manajemen } \\
\text { waktu }\end{array}$ & $53,54 \%$ \\
\hline & & $\begin{array}{l}\text { Perencanaan \& } \\
\text { penataan }\end{array}$ & $31,31 \%$ \\
\hline & \multirow{2}{*}{$\begin{array}{l}\text { Dukungan } \\
\text { sosial }\end{array}$} & $\begin{array}{l}\text { Dukungan } \\
\text { pimpinan }\end{array}$ & $43,94 \%$ \\
\hline & & $\begin{array}{l}\text { Dukungan rekan } \\
\text { kerja }\end{array}$ & $41,92 \%$ \\
\hline \multirow[t]{2}{*}{ Kinerja } & Finansial & $\begin{array}{l}\text { Key } \\
\text { Performance } \\
\text { Indicator }\end{array}$ & $48,48 \%$ \\
\hline & $\begin{array}{l}\text { Non } \\
\text { Finansial }\end{array}$ & Absensi & $31,31 \%$ \\
\hline
\end{tabular}

\section{Uji Hipotesis}

Hasil rekapitulasi pengujian hipotesis dapat dilihat pada Tabel 10. Hipotesis 1 menyatakan bahwa stres kerja memiliki hubungan signifikan terhadap manajemen stres.Pada tabel 11 dapat dilihat $t_{\text {stat }}$ sebesar 1,924 sedangkan nilai $\mathrm{t}_{\text {tabel }}$ pada tingkat signifikan $90 \%$ dan degree of freedom 30 adalah 1,699 maka $t_{\text {stat }}>t_{\text {tabel }}$ sehingga hasil analisis dinyatakan signifikan. Dengan demikian maka hipotesis 1 yang menyatakan bahwa stres kerja berpengaruh positif terhadap manajemen stres dapat diterima.

Dari hasil pengolahan data kuesioner pada Tabel 10 terlihat bahwa stres paling tinggi ditemukan pada indikator adaptasi lingkungan kerja dimana hanya $25,97 \%$ karyawan yang mampu beradaptasi terhadap lingkungan eksternal dengan mudah dan hanya $27,27 \%$ karyawan yang merasakan kemudahan dalam beradaptasi dengan lingkungan internal. Dengan kata lain, lebih dari 70\% karyawan merasakan ketidaknyamanan dalam beradaptasi baik terhadap lingkungan eksternal maupun lingkungan internal perusahaan. Hal ini perlu menjadi perhatian bagi perusahaan agar dapat memperbaiki situasi yang ada menjadi lebih baik lagi. Diperlukan peran para leaders dan dukungan dari departemen SDM di perusahaan untuk dapat membangun budaya kerja yang lebih positif dan memperbaiki suasana bekerja dikantor agar lebih nyaman baik bagi karyawan lama maupun bagi para karyawan baru.

Tingkat stres yang tinggi atau tingkat stres yang rendah namun berkepanjangan dapat mendorong penurunan kinerja karyawan sehingga diperlukan tindakan dari manajemen untuk dapat mengatasinya.Dimana terdapat dua pendekatan dalam mengelola stres yaitu pendekatan individual dan pendekatan organisasional. Pendekatan secara individual dalam mengelola stres dapat dilakukan oleh masing-masing individu diantaranya dengan melakukan manajemen waktu, meningkatkan latihan fisik, meditasi dan memperluas jaringan dukungan sosial. Banyak pekerja memiliki pengelolaan waktu yang kurang baik dan hal tersebut diantaranya dapat dilihat dari jam kerja di kantor yang sering lembur atau pulang malam untuk menyelesaikan pekerjaan.

Pendekatan secara organisasional dalam pengelolaan stres perlu dilakukan oleh perusahaan untuk meningkatkan dan mempertahankan kinerja perusahaan. Pendekatan tersebut tidak hanya dapat dilakukan oleh divisi Sumber Daya Manusia (SDM) namun juga dapat dilakukan oleh level pimpinan di kantor sebagai perwakilan dari organisasi. Pengelolaan stres secara organisasional yang umumnya diselenggarakan oleh divisi sumber daya manusia diantaranya 
dapat dilakukan dengan menyediakan fasilitas klub olahraga dan seni serta mengadakan acara kebersamaan secara berkala. Namun kegiatan ini biasanya dilakukan berskala besar di regional.Sedangkan pengelolaan stres secara organisasional dalam skala kecil dapat dilakukan oleh masing-masing pimpinan unit kerja. Misalnya dengan mengadakan program pulang tepat waktu setiap hari Jumat atau dikenal juga dengan istilah TGIF day, melakukan rapat kerja diluar kantor yaitu di tempat terbuka dengan suasana santai, dan mengadakan kontes bulanan dengan hadiah berupa apresiasi.

Hipotesis 2 menyatakan bahwa kepuasan kerja berpengaruh terhadap manajemen stres. Pada Tabel 11 dapat dilihat $t_{\text {stat }}$ sebesar 2,368 sedangkan nilai $t_{\text {tabel }}$ pada tingkat signifikan $90 \%$ dan degree of freedom 30 adalah 1,699, maka hasil ini menunjukkan kondisi $t_{\text {stat }}>t_{\text {tabel }}$ sehingga hasil analisis dinyatakan signifikan. Dengan demikian maka hipotesis 2 yang menyatakan bahwa kepuasan kerja berpengaruh positif terhadap manajemen stres dapat diterima.
Dari hasil olah data pada Tabel 10 kepuasan terendah yang dirasakan oleh responden adalah kepuasan terhadap pekerjaan dimana hanya $34,09 \%$ karyawan yang merasa puas dengan pekerjaan yang dijalani. Dan hanya 38,38\% karyawan yang merasa sudah cukup puas dengan gaji dan tunjangan yang diberikan oleh perusahaan. Kondisi ini menjelaskan bahwa karyawan merasa tugas dan tanggung jawab yang dipercayakan perusahaan tidak mudah untuk dicapai dan rendahnya semangat karyawan dalam usaha memberikan kontribusi melampaui apa yang diharapkan perusahaan. Dari hasil tersebut perusahaan dapat menentukan strategi selanjutnya agar kepuasan karyawan terhadap pekerjaan menjadi lebih meningkat. Kepuasan terhadap apresiasi dan promosi karyawan di PT Bank X menduduki peringkat paling tinggi yaitu hanya $42,93 \%$ responden menyatakan puas dengan apresiasi dan promosi yang diberikan perusahaan kepada karyawan. Namun angka kepuasan ini masih dibawah 50\% karyawan yang merasakan hal yang sama.

Tabel 10.Hasil Uji Hipotesis

\begin{tabular}{|c|c|c|c|c|c|c|c|c|}
\hline Hipotesis & $\boldsymbol{\alpha}$ & Sig. & $\mathbf{R}$ & $\mathbf{R}$ square & t tabel & t stat & Effect size & Hasil \\
\hline $\mathrm{H} 1: \mathrm{SK} \rightarrow \mathrm{MS}$ & 0,1 & 0,000 & 0,868 & 0,753 & 1,699 & 1,924 & 0,015 & Diterima \\
\hline $\mathrm{H} 2: \mathrm{KK} \rightarrow \mathrm{MS}$ & 0,1 & 0,000 & 0,804 & 0,646 & 1,699 & 2,368 & 0.013 & Diterima \\
\hline $\mathrm{H} 3 \mathrm{:MS} \rightarrow \mathrm{KIN}$ & 0,1 & 0,000 & 0,715 & 0,511 & 1,699 & 12,894 & 0,688 & Diterima \\
\hline
\end{tabular}

Hipotesis 3 menyatakan bahwa manajemen stres berpengaruh terhadap kinerja.Pada Tabel 11 dapat dilihat $t_{\text {stat }}$ sebesar 12,894 sedangkan nilai $t_{\text {tabel }}$ pada tingkat signifikan $90 \%$ dan degree of freedom 30 adalah 1,699, maka hasil tersebut menggambarkan kondisi $t_{\text {stat }}>t_{\text {tabel }}$ sehingga hasil analisis dinyatakan signifikan. Manajemen stres dinyatakan berpengaruh signifikan terhadap kinerja (H3), dilihat dari nilai signifikansinya yaitu 0,000 . Pernyataan ini didukung juga oleh effect size yang bernilai > 0,35 yaitu 0,688 sehingga menunjukkan adanya efek yang cukup besar terhadap variabel kinerja. Berdasarkan pemaparan yang ada, dapat disimpulkan bahwa manajemen stres menjadi mediator bagi stres kerja dan kepuasan kerja terhadap kinerja. Keberadaan manajemen stres di perusahaan dapat memberikan dampak positif bagi karyawan dalam meningkatkan kinerja perusahaan. Hal ini didukung oleh pernyataan bahwa akomodasi dari perusahaan dapat meningkatkan kinerja karyawan dengan menjaga stres pada tingkat yang dapat dikelola (Mellifont dkk, 2016). Dari hasil uji hipotesis yang terdapat pada Tabel 11 dan hasil uji model pada Gambar 2 menjelaskan bahwa pengaruh manajemen stres dalam perannya sebagai mediator antara stres kerja dan kepuasan kerja terhadap kinerja cukup tinggi. Hal ini tercermin dalam hasil perhitungan $\mathrm{t}$ stat yang dihasilkan dari hasil uji model. 
Kesadaran mengenai manajemen stres perlu dipahami dan disadari baik oleh karyawan, karyawan yang menjadi pimpinan (leader) maupun divisi SDM perusahaan. Berdasarkan jawaban responden pada Tabel 10, perencanaan kerja staf di perusahaan menduduki peringkat terendah dimana hanya $31,31 \%$ staf yang melakukan perencanaan kerja berkala. Disarankan kepada masing-masing karyawan agar dalam keseharian melaksanakan tugas dapat melakukan perencanaan kerja yang lebih terstruktur, mengatur waktu kerja agar lebih efektif dan optimal sehingga tidak perlu pulang larut malam.Sehingga karyawan memiliki lebih banyak waktu untuk keluarga dirumah, memiliki waktu istirahat dan tidur yang cukup, memiliki waktu untuk melakukan olah raga rutin agar stamina dan kesehatan fisik tetap terjaga. Selain peran individu, peran pimpinan (leader) dalam mengelola manajemen stres di kantor juga sangat diperlukan. Pimpinan yang dipercaya oleh perusahaan diharapkan mampu memberikan dukungan terhadap tim dibawah supervisinya. Dukungan sosial, kepedulian dan empati dari seorang pimpinan sangat dibutuhkan bagi para karyawan sehingga ketika seorang bawahan mengalami stres akibat tekanan kerja, karyawan tersebut tidak merasa harus menyelesaikan tugas sendiri, melainkan berjuang bersama-sama tim nya. Perbaikan selanjutnya adalah manajemen stres pada indikator dukungan rekan kerja dan dukunan pimpinan. Dimana dari hasil kuesioner ditemukan bahwa hanya 41,92\% karyawan yang merasa setuju bahwa mereka memiliki rekan kerja yang dapat diandalkan dan saling membantu ketika menghadapi permasalahan dalam pekerjaan. Dan hanya $43,94 \%$ karyawan merasakan dukungan sosial dari atasan, dimana karyawan merasa memiliki atasan yang dapat memberikan saran dan solusi dari setiap permasalahan di lapangan, atasan yang bijaksana, dan atasan yang memberikan dorongan semangat kerja yang positif terhadap timnya.

\section{KESIMPULAN}

Penelitian ini dilakukan untuk mendorong para karyawan dan para profesional yang bergerak di bidang usaha perbankan mengenai :
1. Dari hasil penelitian ini ditemukan bahwa peranan manajemen stres memediasi hubungan antara stres kerja dan kepuasan kerja terhadap kinerja karyawan di PT Bank X khususnya di bagian Funding Relationship Manager. Dari hasil uji hipotesis yang terdapat pada Tabel 11 dan hasil uji model pada Gambar 3 menjelaskan bahwa pengaruh manajemen stres dalam perannya sebagai mediator antara stres kerja dan kepuasan kerja terhadap kinerja memiliki peran yang sangat tinggi. Hal ini dibuktikan juga dengan adanya effect size sebesar 0,688.

2. Dari hasil temuan berdasarkan jawaban responden dalam variabel stres ditemukan permasalahan sebagai berikut :

2.1 Hanya $25,97 \%$ karyawan pada perusahaan yang menyatakan setuju bahwa mereka merasa hubungan yang baik dengan pihak eksternal.

2.2 Hanya 27,27\% karyawan pada perusahaan yang menyatakan setuju merasakan hubungan sosial yang baik dengan rekan di kantor dan merasa nyaman bekerja di kantor setiap hari.

2.3 Hanya $29,80 \%$ karyawan yang merasakan suasana lingkungan kantor yang nyaman untuk bekerja dan merasakan kualitas budaya kerja yang positif di lingkungan perusahaan.

2.4 Hanya $33,33 \%$ staf merasa bahwa tugas yang dibebankan cukup jelas.

2.5 Hanya $36,36 \%$ karyawan merasa memiliki peran di dalam tim kerja untuk berkolaborasi saling membangun semangat kerja satu sama lain dan diberikan kepercayaan oleh tim kerja untuk ambil peran dalam mencapai tujuan bersama.

2.6 Hanya 45,96\% karyawan setuju bahwa pekerjaan yang dilakukan setiap hari cukup menantang dan menyenangkan sehingga merasakan suasana hati pada saat beraktivitas dikantor dan energy yang dibutuhkan sepanjang hari tercukupi tanpa merasa kelelahan berkepanjangan.

2.7 Hanya 48,48\% karyawan merasakan bahwa beban kerja yang diberikan 
perusahaan sesuai dengan kapasitas dan kemampuan individu.

3. Dari hasil temuan berdasarkan jawaban responden dalam variabel kepuasan kerja ditemukan permasalahan sebagai berikut :

3.1 Hanya 34,09\% karyawan yang merasa puas dengan pekerjaan yang dibebankan saat ini.

3.2 Hanya 38,38\% karyawan yang merasa puas dengan gaji dan tunjangan yang diterima dari perusahaan.

3.3 Hanya 40,15\% karyawan yang merasakan kepuasan terhadap pimpinan dan perusahaan.

3.4 Hanya 40,91\% karyawan yang merasa puas dengan sesame rekan kerja.

3.5 Hanya 42,93\% karyawan yang merasa puas dengan kebijakan promosi dan apresiasi yang ditentukan oleh perusahaan.

4. Dari hasil temuan berdasarkan jawaban responden dalam variabel manajemen stres ditemukan permasalahan sebagai berikut :

4.1 Hanya 31,31\% karyawan yang memiliki kebiasaan perencanaan dan penataan kerja setiap waktu.

4.2 Hanya $41,92 \%$ karyawan yang mendapatkan dukungan sosial dari rekan kerja.

4.3 Hanya 43,94\% karyawan yang mendapatkan dukungan sosial dari atasan.

4.4 Hanya 53,54\% karyawan yang memiliki kemampuan berstrategi terhadap manajemen waktu untuk menyelesaikan tugas sehari-hari.

5. Dari hasil temuan berdasarkan jawaban responden dalam variabel kinerja ditemukan permasalahan sebagai berikut :

5.1 Hanya $31,31 \%$ karyawan yang jarang sekali tidak masuk, kecuali sedang sakit. Sedangkan sisanya terindikasi sering ijin tidak masuk kerja dengan berbagai alasan diluar kondisi sakit.

5.2 Hanya 48,48\% karyawan yang mampu mencapai minimal $70 \%$ dari target bulanan dan mendapatkan insentif tambahan dalam bentuk tunai dari pencapaian target tersebut. Artinya bahwa sekitar 51,52\% sisanya sering tidak mampu mencapai target yang ditentukan oleh perusahaan dan tidak mendapatkan penghasilan tambahan dalam bentuk insentif tunai.

6. Ditemukan cukup banyak permasalahan yang harus dihadapi oleh perusahan dan membutuhkan perbaikan. Hal ini ditunjukkan dengan hasil kuesioner dimana hanya 2 dari 21 indikator yang direspon oleh responden memberikan angka diatas $80 \%$. Yaitu variabel stres buruk dan variabel degree of feelings. Dimana hanya $10,10 \%$ karyawan yang merasa tidak cocok dengan pekerjaan saat ini. Artinya, karyawan yang direkrut oleh perusahaan untuk penempatan posisi sales Funding Relationship Manager sebenarnya sudah sesuai. Ditemukan pula bahwa $83,33 \%$ merasa memiliki hubungan kerja yang baik dalam tim serta diberikan kepercayaan oleh atasan dan dianggap mampu oleh manajemen untuk memenuhi tugas dan tanggung jawab sesuai jabatan.

\section{SARAN}

Manajemen stres di perusahaan dalam tujuan meningkatkan kinerja di perusahaan nyata sangat diperlukan, karena semakin optimal manajemen stres yang dilakukan akan berdampak terhadap kinerja karyawan. Pihak yang harus mengupayakan manajemen stres tersebut adalah pihak karyawan sebagai individu dan perusahaan sebagai organisasi.

Dalam menerapkan peran manajemen stres secara optimal di perusahaan, penulis menyarankan beberapa hal :

1. Perusahaan menghapuskan ketentuan jam kerja baku Senin hingga Jumat mulai pukul 08.00 17.00 menjadi jam kerja yang lebih fleksibel.

2. Perusahaan menerapkan sistem anti-lembur yang dapat dilakukan serentak sekali dalam seminggu, yaitu pada hari Jumat dengan mematikan server sistem internet di perusahaan pada pukul 17.00 tepat sehingga karyawan dapat pulang lebih awal dan memiliki waktu yang lebih banyak untuk beristirahat di rumah atau melakukan aktivitas lain yang tidak berhubungan dengan pekerjaan. 
3. Perusahaan memperbaiki fasilitas ruang meeting di setiap kantor dengan menambahkan fasilitas mesin pembuat kopi otomatis, microwave dan lemari pendingin berisi makanan kecil dan minuman ringan sehingga pada saat meeting karyawan dapat sambil menikmati kopi.

4. Perusahaan menambahkan tunjangan ulang tahun kepada karyawan tetap yang diberikan satu tahun sekali di bulan ulang tahun karyawan.

5. Perusahaan memberikan cuti ulang tahun kepada karyawan yang berulang tahun.

6. Perusahaan menyediakan fasilitas wifi di setiap kantor cabang sehingga karyawan dapat menikmati akses internet dengan lebih mudah.

7. Perusahaan membangun dan menyediakan sarana khusus sport center di kantor cabang sehingga karyawan dapat melakukan olah raga di kantor saat tidak bertugas.

8. Perusahaan menyediakan fasilitas ruang baca dan ruang musik untuk karyawan.

\section{DAFTAR PUSTAKA}

Ahmad, A., \& Afgan, S. (2016). The Relationship of Job Stress and Turnover Intention in Commercial Banks of Pakistan by Assessing the Mediating Role of Burnout. Journal of Business Strategies, 10(1), 123.

http://search.proquest.com.ezproxy.saintle o.edu/docview/1815437465? accountid=48 70

Alferaih, A. (2015). Conceptual model for measuring Saudi banking managers' job performance based on their emotional intelligence (EI). International Journal of Organizational Analysis, 25(1), 123-145. https://doi.org/10.1108/IJOA-10-20140807

Alhashmi, M., Jabeen, F., Al-Nasser, A. D., \& Papastathopoulos, A. (2017). The antecedents of employee turnover intentions in the police force in the United Arab Emirates: A conceptual framework. International Journal of Business and Society, 18(S3), 449-462.

Amiruddin, A. (2018). Mediating effect of work stress on the influence of time pressure, work-family conflict and role ambiguity on audit quality reduction behavior. International Journal of Law and Management, 61(2), 434-454. https://doi.org/10.1108/JJLMA-09-20170223

Andrade, M. S., \& Westover, J. H. (2019). Global comparisons of job satisfaction across occupational categories. Evidence-Based HRM, 8(1), 38-59. https://doi.org/10.1108/EBHRM-09-20190086

Anjum, A., \& Ming, X. (2017). Combating toxic workplace environment: An empirical study in the context of Pakistan. Journal of Modelling in Management, 13(3), 675697. https://doi.org/10.1108/JM2-022017-0023

Aryee, S., Walumbwa, F. O., Mondejar, R., \& Chu, C. W. L. (2015). Accounting for the influence of overall justice on job performance: Integrating selfdetermination and social exchange theories. Journal of Management Studies, 52(2), 231-252. https://doi.org/10.1111/joms.12067

Badawy, M., El-Aziz, A. A. A., Idress, A. M., Hefny, H., \& Hossam, S. (2016). A survey on exploring key performance indicators. Future Computing and Informatics Journal, 1(1-2), 47-52. https://doi.org/10.1016/j.fcij.2016.04.001

Berry, H. (2018). The Influence of Multiple Knowledge Networks on Innovation in Foreign Operations. Organization Science, 29(5), 855-872. https://doi.org/10.1287/orsc.2018.1203

Bewick, V., Cheek, L., \& Ball, J. (2003). Statistics review 7: Correlation and regression. Critical Care, 7(6), 451-459. https://doi.org/10.1186/cc2401

Chaudhary, P., \& Lodhwal, R. K. (2016). An analytical study of organizational role stress (ORS) in employees of nationalized banks: A case of Allahabad Bank. Journal of Management Development, 36(5), 671680. https://doi.org/10.1108/JMD-09- 
2015-0137

Cheng, C. Y., \& Chang, J. N. (2016). Job embeddedness as a modulation: Goal orientation and job stress in the life insurance $\mathrm{M} \& \mathrm{~A}$. Journal of Organizational Change Management, 29(4), 484-507. https://doi.org/10.1108/JOCM-10-20140184

Chou, L. F., Chu, C. C., Yeh, H. C., \& Chen, J. (2014). Work stress and employee wellbeing: The critical role of Zhong-Yong. Asian Journal of Social Psychology, $17(2)$, 115-127. https://doi.org/10.1111/ajsp.12055

Clark, V. L. P., \& Creswell, J. W. (2015). Understanding Research (Second). Pearson Education Inc.

Connelly, S., \& Torrence, B. S. (2018). The relevance of discrete emotional experiences for human resource management: Connecting positive and negative emotions to HRM. Research in Personnel and Human Resources Management, $36, \quad 1-49$. https://doi.org/10.1108/S0742730120180000036001

Corbett, M. (2014). From law to folklore: Work stress and the Yerkes-Dodson Law. Journal of Managerial Psychology, 30(6), 741-752. https://doi.org/10.1108/JMP-032013-0085

Dipboye, R. L. (2018). Occupational Stress. In The Emerald Review of Industrial and Organizational Psychology. https://doi.org/10.1108/978-1-78743-785220181008

Doe, F., Puplampu, B. B., \& Preko, A. (2020). Causes of coercive management behaviour, dimensions and occupations. International Journal of Organizational Analysis. $\quad$ https://doi.org/10.1108/IJOA01-2019-1640

Fabi, B., Lacoursière, R., \& Raymond, L. (2014). Impact of high-performance work systems on job satisfaction, organizational commitment, and intention to quit in Canadian organizations. International
Journal of Manpower, 36(5), 772-790. https://doi.org/10.1108/IJM-01-2014-0005

Garg, R., \& Garg, R. (2018). Organizational Factors That Affect Service Delivery in the Hospitality Sector. IUP Journal of Marketing Management, 17(3), 50-84. http://proxy.library.tamu.edu/login?url=ht tps://search.proquest.com/docview/21049 63535 accountid=7082\%0Ahttp://linkreso lver.tamu.edu:9003/tamu?url_ver=Z39.88

2004\&rft_val_fmt=info:ofi/fmt:kev:mtx:j ournal\&genre=article \&sid=ProQ:ProQ\%3 Aabiglobal\&atitle=Orga

George, E., \& Zakkariya, K. A. (2014). Job related stress and job satisfaction: A comparative study among bank employees. Journal of Management Development, 34(3), 316-329. https://doi.org/10.1108/JMD-07-20130097

Gong, T., \& Wang, C. Y. (2019). How does dysfunctional customer behavior affect employee turnover. Journal of Service Theory and Practice, 29(3), 329-352. https://doi.org/10.1108/JSTP-04-20180081

Grissom, J., Loeb, S., \& Mitani, H. (2015). Principal time management skills: explaining patterns in principals' time use, job stress, and perceived effectiveness In. Journal of Educational Administration, 8(5), $\quad$ ebi-ebi. https://doi.org/10.1080/2159676x.2016.12 21912

Gupta, A., \& Xia, C. (2018). A paradigm shift in banking: Unfolding asia's fintech adventures. In International Symposia in Economic Theory and Econometrics (Vol. 25). https://doi.org/10.1108/S1571038620180000025010

Gyensare, M. A., Anku-Tsede, O., Sanda, M.-A., \& Okpoti, C. A. (2016). Transformational leadership and employee turnover intention. World Journal of Entrepreneurship, Management and Sustainable Development, 12(3), 243266. https://doi.org/10.1108/wjemsd-02- 
2016-0008

Habeeb, S. (2019). Assessment of behavior-based performance in banking and insurance sector. International Journal of Productivity and Performance Management, 69(7), 1345-1371. https://doi.org/10.1108/IJPPM-02-20190074

Hakim, L., \& Sugiyanto, E. (2017). Manajemen Stres Kerja Pengusaha Untuk Meningkatkan Kinerja Perusahaan Di Industri Batik Laweyan Surakarta. Benefit: Jurnal Manajemen Dan Bisnis, 2(1), 45. https://doi.org/10.23917/benefit.v2i1.3198

He, K., Zhang, J., Feng, J., Hu, T., \& Zhang, L. (2016). The Impact of Social Capital on farmers' Willingness to Reuse Agricultural Waste for Sustainable Development. Sustainable Development, 24(2), 101-108. https://doi.org/10.1002/sd.1611

Jonasson, C., Lauring, J., Selmer, J., \& Trembath, J. L. (2017). Job resources and demands for expatriate academics: Linking teacherstudent relations, intercultural adjustment, and job satisfaction. Journal of Global Mobility, 5(1), 5-21. https://doi.org/10.1108/JGM-05-20160015

Jung, H. S., \& Yoon, H. H. (2019). The effects of social undermining on employee voice and silence and on organizational deviant behaviors in the hotel industry. Journal of Service Theory and Practice, 29(2), 213231. https://doi.org/10.1108/JSTP-062018-0131

Jyoti, J., \& Kour, S. (2017). Factors affecting cultural intelligence and its impact on job performance: Role of cross-cultural adjustment, experience and perceived social support. Personnel Review, 46(4), 767-791. https://doi.org/10.1108/PR-122015-0313

Kaur, N., \& Kang, L. S. (2019). The costs and benefits of going beyond the call of duty. International Journal of Productivity and Performance Management, 69(2), 252-
270. https://doi.org/10.1108/IJPPM-012019-0035

Koopmann, J., Wang, M., Liu, Y., \& Song, Y. (2015). Customer mistreatment: A review of conceptualizations and a multilevel theoretical model. Research in Occupational Stress and Well Being, 13, 33-79. https://doi.org/10.1108/S1479355520150000013002

Kozusznik, M. W., Rodríguez, I., \& Peiró, J. M. (2015). Eustress and distress climates in teams: Patterns and Outcomes. International Journal of Stress Management, 22(1), 1-23. https://doi.org/10.1037/a0038581

Kunasegaran, M., Ismail, M., Mohd Rasdi, R., Arif Ismail, I., \& Ramayah, T. (2016). Talent development environment and workplace adaptation: The mediating effects of organisational support. European Journal of Training and Development, $\quad 40(6), \quad 370-389$. https://doi.org/10.1108/EJTD-07-20150060

Ling, F. Y. Y., \& Wong, D. M. G. (2015). Redesigning facility management operatives' jobs to increase work outcomes. Journal of Facilities Management, 14(1), 50-68. https://doi.org/10.1108/JFM-11-20140036

Mellifont, D., Smith-Merry, J., \& Scanlan, J. N. (2016). Pitching a Yerkes-Dodson curve ball?: A study exploring enhanced workplace performance for individuals with anxiety disorders. Journal of Workplace Behavioral Health, 31(2), 7186.

https://doi.org/10.1080/15555240.2015.11 19654

Mirabito, A. M., \& Berry, L. L. (2015). You Say You Want a Revolution? Drawing on Social Movement Theory to Motivate Transformative Change. Journal of Service Research, 18(3), 336-350. https://doi.org/10.1177/109467051558203 7

Moustaghfir, K., Schiuma, G., \& Carlucci, D. 
(2016). Rethinking performance management: A behaviour-based perspective. International Journal of Innovation and Learning, 20(2), 169-184. https://doi.org/10.1504/IJIL.2016.077848

Mulki, Jay P., \& Wilkinson, J. W. (2017). Customer-directed extra-role performance and emotional understanding: Effects on customer conflict, felt stress, job performance and turnover intentions. Australasian Marketing Journal, 25(3), 206-214.

https://doi.org/10.1016/j.ausmj.2017.04.0 02

Mulki, Jay Prakash, Jaramillo, F., Goad, E. A., \& Pesquera, M. R. (2015). Regulation of emotions, interpersonal conflict, and job performance for sales people. Journal of Business Research, 68(3), 623-630. https://doi.org/10.1016/j.jbusres.2014.08.0 09

Nandan, S., Halkias, D., Thurman, P. W., Komodromos, M., Alserhan, B. A., Adendorff, C., Yahaya Alhaj, N. H. Y., De Massis, A., Galanaki, E., Juma, N., Kwesiga, E., Nkamnebe, A. D., \& Seaman, C. (2018). Assessing crossnational invariance of the threecomponent model of organizational commitment: A cross-country study of university faculty. EuroMed Journal of Business, 13(3), 254-279. https://doi.org/10.1108/EMJB-09-20170031

Nasr, L., Burton, J., \& Gruber, T. (2015). When good news is bad news: the negative impact of positive customer feedback on front-line employee well-being. Journal of Services Marketing, 29(6-7), 599-612. https://doi.org/10.1108/JSM-01-20150052

Paais, M. (2018). Effect of work stress, organization culture and job satisfaction toward employee performance in Bank Maluku. Academy of Strategic Management Journal, 17(5), 1-13.

Rao, A. S., Kareem Abdul, W., \& D'souza, N. (2017). Perceived outcomes of action learning: study from a large public sector organization in UAE. Measuring Business Excellence, 21(4), 291-308. https://doi.org/10.1108/MBE-03-20170010

Reidolf, M. (2016). Knowledge networks and the nature of knowledge relationships of innovative rural SMEs. European Journal of Innovation Management, 19(3), 317336. https://doi.org/10.1108/EJIM-062015-0043

Robbins, S. P., \& Judge, T. A. (2017). Organizational Behavior (17th ed.).

Sahadev, S., Purani, K., \& Kumar Panda, T. (2016). Service employee adaptiveness: Exploring the impact of role-stress and managerial control approaches. Employee Relations, $\quad 39(1), \quad$ 54-78. https://doi.org/10.1108/ER-11-2015-0213

Sakr, C., Zotti, R., \& Khaddage-Soboh, N. (2019). The impact of implementing fun activities on employee's engagement: The case of Lebanese financial institutions. International Journal of Organizational Analysis, 27(5), 1317-1335. https://doi.org/10.1108/IJOA-09-20181527

Sarfraz, H. (2017). Differentiated time management skills between leadership styles: simplified with a cross-cultural approach. Development and Learning in Organizations, 31(6), 14-18. https://doi.org/10.1108/DLO-02-20170009

Sarstedt, M., \& Cheah, J. H. (2019). Partial least squares structural equation modeling using SmartPLS: a software review. Journal of Marketing Analytics, 7(3), 196-202. https://doi.org/10.1057/s41270019-00058-3

Schonstrom, M. (2005). Creating knowledge networks: lessons from practice. Journal of Knowledge Management, 9(6), 17. https://doi.org/DOI 10.1108/13673270510629936

Schoonenboom, J., \& Johnson, R. B. (2017). How to Construct a Mixed Methods Research Design. Kolner Zeitschrift Fur Soziologie 
Und Sozialpsychologie, 69, 107-131. https://doi.org/10.1007/s11577-017-04541

Sharma, P., Kong, T. T. C., \& Kingshott, R. P. J. (2016). Internal service quality as a driver of employee satisfaction, commitment and performance: Exploring the focal role of employee well-being. Journal of Service Management, 27(5), 773-797. https://doi.org/10.1108/JOSM-10-20150294

Smith, R. E., \& Ascough, J. C. (2016). Promoting emotional resilience.

Srivastava, S., \& Dey, B. (2019). Workplace bullying and job burnout: A moderated mediation model of emotional intelligence and hardiness. International Journal of Organizational Analysis, 28(1), 183-204. https://doi.org/10.1108/IJOA-02-20191664

Strutton, D., \& Tran, G. A. (2014). How to convert bad stress into good. Management Research Review, 37(12), 1093-1109. https://doi.org/10.1108/MRR-06-20130139

Swalhi, A., Zgoulli, S., \& Hofaidhllaoui, M. (2017). The influence of organizational justice on job performance: The mediating effect of affective commitment. Journal of Management Development, 34(1), 1-5. https://doi.org/Journal of Management Development The influence of organizational justice on job performance: The mediating effect of affective commitment Abdelaziz Swalhi, Saloua Zgoulli, Mahrane Hofaidhllaoui, Article information: To cite this document: Abdelaziz Swalhi, Saloua Zgoulli, Mahrane Hofaidhllaoui, (2017) "The influence of organizational justice on job performance: The mediating effect of affective commitment", Journal of Management Development, Vol. 36 Issue: 4, pp.542-559, https://doi.org/10.1108

Tagoe, T., \& Amponsah-Tawiah, K. (2019). Psychosocial hazards and work engagement in the Ghanaian banking sector: The moderating role of psychosocial safety climate. International Journal of Bank Marketing, 38(2), 310331. https://doi.org/10.1108/IJBM-042019-0136

Tsai, S. pei. (2018). Innovative behaviour of knowledge workers and social exchange attributes of financial incentive: implications for knowledge management. Journal of Knowledge Management, 22(8), $1712-1735$. https://doi.org/10.1108/JKM-07-20170293

Utami, T. L. W., Indarti, N., Sitalaksmi, S., \& Makodian, N. (2017). The Effect of Knowledge Sources on Innovation Capabilities Among Restaurants and Cafe Business in Indonesia. Journal of Indonesian Economy and Business, 32(1), 33-50.

van Gelderen, B. R., \& Bik, L. W. (2016). Affective organizational commitment, work engagement and service performance among police officers. Policing, 39(1), 206-221. https://doi.org/10.1108/PIJPSM-10-20150123

Wong, K. K. K.-K. (2013). 28/05 - Partial Least Squares Structural Equation Modeling (PLS-SEM) Techniques Using SmartPLS. Marketing Bulletin, 24(1), 1-32. http://marketingbulletin.massey.ac.nz/v24/mb_v24_t1_wo ng.pdf\%5Cnhttp://www.researchgate.net/ profile/Ken_Wong10/publication/268449 353_Partial_Least_Squares_Structural_Eq uation_Modeling_(PLSSEM)_Techniques_Using_SmartPLS/link s/54773b1b0cf293e2da25e3f3.pdf

Yin, R. K. (2015). Qualitative Research from Start to Finish (2nd ed.). The Guilford Press.

Yin, R. K. (2018). Designing Case Studies. In Case Study Research and Applications: Design and Methods. 